\title{
Review Article \\ Recent Advances in the Genetic Transformation of Coffee
}

\author{
M. K. Mishra ${ }^{1}$ and A. Slater ${ }^{2}$ \\ ${ }^{1}$ Central Coffee Research Institute, Coffee Research Station, Chikmagalur, Karnataka 577117, India \\ ${ }^{2}$ The Biomolecular Technology Group, Faculty of Health and Life Sciences, De Montfort University, Gateway, \\ Leicester LE1 9BH, UK \\ Correspondence should be addressed to M. K. Mishra, manojmishra.m@gmail.com
}

Received 13 March 2012; Revised 18 June 2012; Accepted 28 June 2012

Academic Editor: Shengwu Ma

Copyright ( $) 2012$ M. K. Mishra and A. Slater. This is an open access article distributed under the Creative Commons Attribution License, which permits unrestricted use, distribution, and reproduction in any medium, provided the original work is properly cited.

Coffee is one of the most important plantation crops, grown in about 80 countries across the world. The genus Coffea comprises approximately 100 species of which only two species, that is, Coffea arabica (commonly known as arabica coffee) and Coffea canephora (known as robusta coffee), are commercially cultivated. Genetic improvement of coffee through traditional breeding is slow due to the perennial nature of the plant. Genetic transformation has tremendous potential in developing improved coffee varieties with desired agronomic traits, which are otherwise difficult to achieve through traditional breeding. During the last twenty years, significant progress has been made in coffee biotechnology, particularly in the area of transgenic technology. This paper provides a detailed account of the advances made in the genetic transformation of coffee and their potential applications.

\section{Introduction}

Coffee is one of the most important agricultural commodities, ranking second in international trade after crude oil. The total global production of green coffee is above 134.16 million bags ( $60 \mathrm{~kg}$ capacity) with a retail sales value in excess of $\$ 22.7$ billion during 2010-11 in the world market [1]. Coffee is grown in about 10.2 million hectares land spanning over 80 countries in the tropical and subtropical regions of the world especially in Africa, Asia, and Latin America. The economics of many coffee growing countries depends heavily on the earnings from this crop. More than 100 million people in the coffee growing areas worldwide derive their income directly or indirectly from the produce of this crop.

Coffee trees belong to the genus Coffea in the family Rubiaceae. The genus Coffea L. comprises more than 100 species [2], of which only two species, that is, C. arabica (arabica coffee) and C. canephora (robusta coffee), are commercially cultivated. Another coffee species, Coffea liberica is also cultivated in a small scale to satisfy local consumption. Almost all the coffee species are diploid $(2 \mathrm{n}=2 \mathrm{x}=22)$ and generally self-incompatible except $C$. arabica which is a natural allotetraploid $(2 \mathrm{n}=4 \mathrm{x}=44)$ self-fertile species [3]. In the consumer market, C. arabica is preferred for its beverage quality, aromatic characteristics, and low-caffeine content compared to robusta, which is characterized by a stronger bitterness, and higher-caffeine content. Arabica contributes towards $65 \%$ of global coffee production [4].

C. arabica is mainly native to the highlands of Southwestern Ethiopia with additional populations in South Sudan (Boma Plateau) and North Kenya (Mount Marsabit) [58]. The C. arabica varieties grown all over the world are derived from either the "Typica" or "Bourbon" genetic base, which has resulted in low-genetic diversity among cultivated arabicas. In contrast, C. canephora has a wide geographic distribution, extending from the western to central tropical and subtropical regions of the African continent, from Guinea and Liberia to Sudan and Uganda with high genetic diversity in the Democratic Republic of Congo [9]. C. canephora maintains heterozygosity due to its cross-pollinating nature.

\section{Coffee Breeding and Its Limitations}

Coffee breeding is largely restricted to the two species, C. arabica and C. canephora, that dominate world coffee production. However, C. liberica and C. congensis have contributed useful characters to the gene pool of $C$. arabica 
and C. canephora, respectively, through natural and artificial interspecific hybridisation. In C. arabica, initial breeding objectives were to increase productivity and adaptability to local conditions. To achieve these objectives, breeding strategies were directed towards identification of superior plants in the population and their propagation and crossing with existing cultivars. These early breeding efforts, which were carried out from 1920 to 1940, had considerable success in identifying and developing vigorous and productive cultivars. Several of these varieties such as Kents and S.288 from India, Mundo Novo, Caturra and Catuai from Brazil, and Blue Mountain from Jamaica, are still under commercial cultivation. These cultivars are suggested to have a larger degree of genetic variability than the base population [10]. The appearance of coffee leaf rust (Hemileia vastatrix Berk and $\mathrm{Br}$ ) in epidemic scale in Southeast Asia between 1870 and 1900 had a devastating effect on arabica coffee cultivation in several coffee growing countries. This has changed the breeding focus worldwide with emphasis now given to disease resistance. This has resulted in the introduction of other tolerant species, especially C. canephora, in many countries. Until now, C. canephora has provided the major source of disease and pest resistance traits such as coffee leaf rust ( $H$. vastatrix), coffee berry disease (Colletotrichum kahawae), and root-knot nematode (Meloidogyne spp.) not available in C. arabica. Besides, C. canephora, other diploid species such as $C$. liberica has been used as source of resistance to leaf rust [11] and C. racemosa for imparting resistance to coffee leaf minor [12]. Further, the cultivation of $C$. arabica with other diploid species such as C. canephora and $C$. liberica in close proximity has resulted in spontaneous hybrids in many countries. Natural interspecific hybrids such as Hybrido-de Timor (a hybrid between C. arabica and $C$. canephora [13] from Timor island), Devamachy (a hybrid between C. arabica and C. canephora), and S.26 (a hybrid between $C$. arabica and C. liberica, which both originated in India [14]) are the main source of resistance to pest and disease and extensively used in $C$. arabica breeding programmes.

Like C. arabica, improvement of C. canephora was originally aimed at increasing productivity, and improving bean size and liquor quality. The breeding methods adopted for $C$. canephora involvedmass selection and intra- as well as interspecific hybridization. Varieties like Apoata of Brazil, S.274 of India, and Nemaya of Central America were derived through mass selection. The spontaneous diploid interspecific hybrid between C. canephora var. ugandae and the C. congensis (called Congusta in Indonesia), and the C $\times \mathrm{R}$ hybrid variety developed through artificial hybridisation between C. congensis and C. canephora in India are examples of improved robusta cultivars developed through interspecific hybridisation.

Although conventional breeding is mainly used for coffee improvement, it is a long process involving several different techniques, namely selection, hybridization, and progeny evaluation. A minimum of 30 years is required to develop a new cultivar using any of these methods. Further, the long generation time of the coffee tree, the high cost of field trials, the lack of accuracy of the breeding process, the differences in ploidy level between C. arabica and other diploid species, and the incompatibility are all major limitations associated with conventional coffee breeding. In addition to these, genetic resistance to coffee white stem borer (Xylotrechus quadripes) and coffee berry borer (Hypothenamus hampei), drought and cold tolerance, and herbicide resistance are some of the features that are not easily available in the coffee gene pool or are difficult to incorporate using conventional breeding. Another constraint that hinders the arabica coffee improvement programme is the selection of genetically diverse parental lines for hybridization and the identification of hybrids at an early stage of plant growth based on morphological traits. This is because most of the commercial arabica cultivars are morphologically identical and not easily distinguishable from one another. Uniformity of morphological traits in C. arabica could be attributed to the origin of the species, its narrow genetic base and self-fertile nature. In coffee, identification of cultivars is mainly based upon phenotypic features, but this approach is not reliable and is subject to environmental influences, mainly because of the long generation time of the coffee trees. In some countries of Asia, Latin America, and Africa, coffee is cultivated under shade in varied agroclimatic conditions and displays remarkably different morphologies in various microclimatic zones. In view of the above, it becomes imperative to develop alternative techniques that are reliable, quick, and efficient for discriminating between coffee cultivars. Among the various markers available for genetic analysis in coffee, molecular markers are more efficient, precise, and reliable than other markers for discriminating closely related species and cultivars. The DNA-based markers have the potential of complimenting coffee breeding and improvement program in form of marker-assisted selection (MAS).

\section{Molecular Markers and Coffee Genetic Improvement}

Various molecular markers, such as restriction fragment length polymorphism (RFLP), random amplified polymorphic DNA (RAPD), amplified fragment length polymorphism (AFLP), intersimple sequence repeat (ISSR), simple sequence repeats (SSR), and expressed sequence tag derived simple sequence repeats (EST-SSR) have been used in coffee genetic diversity studies [46-51]. In addition to the above, a large number of commercial coffee samples of American, Indian, and African origin were also analyzed using highly polymorphic SSR markers which revealed that Indian cultivars were genetically diverse from the American and African cultivars [52]. More recently, a new type of molecular marker known as a sequence related amplified polymorphism (SRAP) was used in genetic diversity analysis of coffee cultivars and species [53, 54]. SRAP markers were also successfully used to discriminate between parents in hybrid identification $[55,56]$ and therefore has great potential in coffee breeding programmes. In addition to the above, single-nucleotide polymorphisms (SNPs) and PCR-RFLP markers were used in coffee genome analysis, which revealed that in C. arabica, polymorphisms are 
created by paralogous chromosomes, whereas homozygosity of many genes is maintained by the self-fertile nature of the species [57]. These results further demonstrated that in allopolyploid C. arabica, the two parental genomes remain separated and exhibit multiple allelic inheritance patterns, and these findings will be very important for designing strategies and decisions in breeding programmes as well as in sequencing projects. In recent years, concerted efforts have been made by several laboratories across the world, under the International Coffee Genome Network (ICGN) programme, to sequence the coffee genome by using high-throughput sequencing technology which will unravel several key aspects of the coffee genome that may be useful for coffee genetic improvement. In addition to molecular markers, a twodimensional protein mapping technique was also used to differentiate green coffee samples [58]. A detailed review of the role of various molecular markers in coffee is already available [59] and therefore beyond the scope of the present review.

\section{The Need for Genetic Transformation of Coffee}

Since its initial application to plants more than 25 years ago, genetic transformation has become an indispensable tool in plant molecular biology and functional genomics research [60]. Genetic transformation technology is considered as an extension of conventional plant breeding technologies [61]. It offers unique breeding opportunities by introducing novel genetic material irrespective of the species barrier and creating phenotypes with desired traits that are not available in the germplasm pool of crop plants. The major objectives for using genetic engineering technique in coffee are to introduce new traits in to elite coffee genotypes, develop new cultivars with desirable traits such as pest and disease resistance, herbicide resistance, drought and frost tolerance, and improved cup quality, which are not possible to incorporate using traditional breeding techniques. The recent developments in coffee transcriptomics and the availability of large amounts of expressed sequence tag (EST) data from both C. canephora and C. arabica [62-64], as well as the development of coffee bacterial artificial chromosome (BAC) genomic libraries [65, 66], have opened up new possibilities in the area of coffee functional genomics. A key component of most functional genomics approaches is the availability of a highly efficient transformation system useful for designing strategies for gene identification, elucidation of gene functions, regulation and interaction of genes and gene expression analysis to understand the involvement of genes, in coffee biological processes. This will help in precisely targeting the trait of interest using various transformation tools (genes and promoters) with increase probability of success in reducing economic costs.

Genetically modified coffee plants have been produced by different research groups in the world $[21,25,26,29$, $34,37,67]$. Despite significant advances over the last 20 years, coffee transformation is far from a routine procedure in many laboratories [35]. The objective of this paper is to provide an update on coffee genetic transformation over the last decade, including the in vitro methods used for plant generation.

\section{In Vitro Plant Regeneration}

The establishment of an efficient regeneration system is important for genetic transformation of coffee. Various in vitro multiplication methods such as somatic embryogenesis, meristem and axillary bud culture, and induction of adventitious buds have been reported using different types of tissue in various coffee species $[68,69]$.

5.1. Somatic Embryogenesis. The initiation and development of embryos from somatic tissues without the involvement of sexual fusion are known as somatic embryogenesis. In coffee, induction of somatic embryogenesis and plant regeneration was first reported from the internodal explants of C. canephora [70]. In C. arabica, calluses were successfully induced from seeds, leaves, and anthers of two different cultivars, that is, Mundo Novo and Bourbon Amarelo [71]. During the last 35 years, a number of protocols for somatic embryogenesis have been developed for various genotypes of coffee [68]. The first protocol to obtain calli with high embryogenic potential from the leaf explants of C. arabica cv. Bourbon used two different culture media compositions: a first "conditioning" medium and a second "induction" medium [72, 73]. The availability of auxins is critical for the induction of embryogenic calli [72]. In coffee, both high-frequency somatic embryogenesis (HFSE) and lowfrequency somatic embryogenesis (LFSE) were established. 2,4-D strongly increases HFSE in combination in primary cultures where as IBA and NAA combined with $\mathrm{K}$ increase LFSE. During somatic embryo induction in C. arabica cv. Caturra Rojo, two types of cell clusters, embryogenic and nonembryogenic were observed [74]. The differences in gene expression at both RNA and protein levels were observed between the embryogenic and nonembryogenic cell clusters. Further, it was observed that the number of genes turned off in somatic cells to allow for the change from somatic to embryogenic state is higher than those genes that are turned on [74].

In coffee, somatic embryogenesis follows two distinct developmental patterns: (1) direct somatic embryogenesis, where embryos originate directly from the explants and (2) indirect somatic embryogenesis, where embryos are derived from an embryogenic dedifferentiated tissue (callus). However, both direct and indirect somatic embryos of coffee formed from leaf segments and callus, respectively, have a unicellular origin [75]. Various attempts were made to reduce the time needed for embryogenesis and increase the embryogenesis frequency in coffee. Triacontanol, silver nitrate $\left(\mathrm{AgNO}_{3}\right)$, salicylic acid, thidiazuron, and 6-(3methyl-3-butenylamino) purine (2ip) are the widely used growth regulators in coffee embryogenesis. Interestingly, picomolar concentrations of salicylates reported to induce cellular growth and enhance somatic embryogenesis in C. arabica tissue culture [76]. Similarly, triacontanol, as 
well as silver nitrate, at low concentration in combination with indole-3-acetic acid (IAA) and benzyladenine (BA) induced direct somatic embryogenesis in both species of C. arabica and C. canephora [77, 78]. Additionally, thidiazuron (TDZ) also induced direct somatic embryos from the cultured leaf explants of $C$. canephora $\mathrm{cv}$. $\mathrm{C} \times \mathrm{R}$ [79]. In C. canephora, the embryogenic response of the explants has been shown to increase by the addition of polyamines, either alone or in combination with silver nitrate. It has been observed that incorporation in the in vitro culture medium of inhibitors of the polyamine biosynthetic pathway such as D,L-.alpha-difloromethylornithine (DFMO) and D,L-.alpha-difloromethylarginine (DFMA) significantly reduced the embryogenic response of the explants in C. canephora, indicating the pivotal role played by polyamines in coffee somatic embryogenesis [80]. Besides the polyamines, indoleamines (melatonin and serotonin) as well as calcium and calcium ionophores (A23187) have also been shown to be beneficial in inducing somatic embryogenesis [81]. Apart from exogenous growth hormones, ethylene and dissolved oxygen concentration play a crucial role in coffee somatic embryogenesis [82, 83].

The use of somatic embryos on an industrial scale was achieved by inducing somatic embryos of $C$. arabica in liquid medium using bioreactors [84, 85]. The yield of embryos achieved was about 46,000 embryos/3L Erlenmeyer flask (after 7 weeks of culture). Various other workers also reported the production of somatic embryos for industrial use $[86,87]$. Extensive studies were carried out in the use of conventional and temporary immersion system for coffee somatic embryo production [68, 88, 89]. However, to date the major obstacle associated with production of somatic embryos on a commercial scale is synchronisation of embryogenesis and conversion of plantlets.

5.2. Micropropagation. The coffee plant has a single apical meristem with each axil leaf having 4-5 dormant orthotropic buds and two plagiotropic buds. The plagiotropic buds only start development from the 10th to 11 th node. For apical meristem culture and the culture of dormant buds, both orthotropic and plagiotropic buds were cultured for obtaining plantlets. Microcuttings or nodal culture comprise a tissue culture approach which involves culturing nodal stem segments carrying dormant auxiliary buds and stimulating them to develop. Each single segment can provide 7-9 microcuttings every eighty days. Most of these studies were carried out during the 1980s, and these topics have been reported in an earlier review [68].

Several studies have been carried out with a view to micropropagating superior coffee genotypes using apical or axillary meristem culture and nodal culture [68]. A maximum of nine shoots was obtained per one shoot explant [90]. Culture of microcuttings in a temporary immersion system resulted in a 6 -fold increase in the multiplication rate, in comparison with microcuttings multiplied on solid medium $[91,92]$. The field performance of embryogenerated plants was reported and showed a normal response in terms of physiology and yield. The genetic fidelity of micropropagated plants of C. canephora obtained through somatic embryogenesis was assessed in a large-scale field trial [93]. A total number of 5067 trees regenerated from five to 7-month-old embryogenic cell suspension cultures were planted in the Philippines and in Thailand for comparison with control plants derived from auxiliary budding in vitro. No significant differences in yield and morphological features were observed between the somatic seedlings and microcutting derived trees [93]. However, in contrast to the above, several studies have clearly demonstrated cultureinduced variation and regeneration of somaclonal variants in coffee obtained through direct and indirect somatic embryogenesis [94-96]. Detailed molecular analysis of the plantlets of $C$. arabica derived from high-frequency somatic embryogenesis revealed alterations in both the nuclear and mitochondrial genomes [97]. These reports therefore proposed a critical evaluation of tissue culture-derived plants both at phenotypic and molecular level.

Adventitious shoot development is an alternative method of coffee micropropagation. Shoots originating in tissues located in areas other than leaf axils or shoot tips are subjected to one phase of dedifferentiation followed by differentiation and morphogenesis $[68,98]$. Rooting is the most difficult and expensive phase of the micropropagation process, and the success of newly formed plantlets is closely linked to the ability of the root system to adapt to the autotrophic conditions. Several studies have been carried out to improve the rate of rooting of micropropagated plants [68].

\section{Development of Transgenic Coffee}

Genetic engineering research on coffee has been pursued for the past fifteen years with two major objectives: (1) to elucidate the function, regulation, and interaction of agronomically important genes through a functional genomics approach and (2) to improve coffee genotypes with desirable traits through the introduction of targeted genes.

6.1. Candidate Genes. In recent years, the development in high-throughput sequencing (HTS) technologies has allowed the rapid acquisition of significant amounts of sequence data, and this has increased our understanding of the genomics of a particular species. During the last decade, significant progress has been made in developing an EST database for coffee. Initial efforts in developing ESTs in Coffea arabica were initiated by the University of Trieste, Italy, and the EST sequences have been placed in the public domain (http://www.coffee.dna.net/). In a private/public collaboration between Nestle and Cornell University, 47000 ESTs from C. canephora were established comprising 13175 unigenes [63]. Subsequently the Brazilian government funded an ambitious coffee genome program, and this has resulted in the establishment of 200000 ESTs which led to the identification of 30000 genes [64]. Very recently, the Italian group has generated an additional 161660 ESTs which will be publicly available at the website (http://www.coffeedna.net/ [99]). In parallel with the development of EST database, 
BAC libraries of coffee species, C. arabica and C. canephora were established $[65,66]$. Such maps are of central strategic importance for marker-assisted breeding, positional cloning of agronomical important genes, and analysis of gene structure and function.

Due to the concerted efforts on coffee genomics, many candidate genes from coffee have been identified and some of them have been cloned and are currently being characterised. These include a caffeine biosynthesis gene $[28,100]$, a sucrose synthase gene [66], osmotic stress response genes [101], genes for seeds oil content [102] and several pathogen resistance genes such as Mex-1 gene [103], $\mathrm{SH}_{3}$ gene [104], and $C k-1$ gene to CBD [105]. An efficient genetic transformation protocol is necessary in order to validate the structural and functional aspects of these intrinsic genes. In coffee transformation experiments, genes isolated from coffee as well as from heterologous sources have been used. Some of the genes isolated from coffee used in transformation experiments include a theobromine synthase gene (CaMXMTI) for suppressing caffeine biosynthesis $[28,106]$ and an ACC oxidase gene involved in ethylene biosynthesis [34]. The genes introduced to coffee from heterologous sources include a cry $1 \mathrm{Ac}$ gene from Bacillus thuringiensis targeted against leaf miner [26], the $\alpha$-AII gene from common bean for imparting resistance to coffee berry borer [30], the $B A R$ gene for herbicide tolerance $[21,35]$, and the homeobox gene WUSCHEL (WUS) from Arabidopsis responsible for stem cell identity [36]. The functional significance and expression of these transgenes in coffee plants are described subsequently in this paper.

6.2. Promoters. In most of the coffee transformation experiments reported so far, with few exceptions, the CaMV35S promoter derived from cauliflower mosaic virus is extensively used in transgenic constructs (See Table 1). In a comparative study made earlier, the efficacy of different promoters driving uidA transient expression in endosperm, somatic embryos, and leaf explants of $C$. arabica was analyzed using microprojectile bombardment $[18,19]$. It was observed that the EF- $1 \alpha$ promoter (from Arabidopsis thaliana EF- $1 \alpha$ translation elongation factor) directed maximum transient expression of the uidA gene compared to other promoters [18]. Therefore, this promoter was used subsequently by the same group in Agrobacterium gene constructs, driving the crylAc gene for the control of leaf miner in coffee $[26,33]$. The efficacy of the CaMV35S viral promoter was also compared with two coffee promoters $(\alpha-$ tubulin and $\alpha$-arabicin) which have revealed a similar level of transient uidA gene expression [19]. These findings have opened up the possibility of using coffee specific promoter in transformation experiments.

6.3. Reporter Genes. Reporter genes are used in gene constructs to optimize the transformation procedure. In the majority of coffee transformation experiments, the uidA gene is used as a reporter gene (See Table 1). Only recently have the $s g f p$ (synthetic green fluorescence protein) and DsRFP (Red fluorescent protein) been used in coffee transformation
$[28,31,37]$. However, most transient expression studies have been carried out using the uidA reporter gene. In an effort to optimize the Agrobacterium transformation protocol in coffee, the expression of the uidA gene driven by a CaMV35S promoter was compared in various tissues under different cocultivation conditions [27]. It was observed that the endogenous GUS activity was reduced substantially when $20 \%$ methanol was added to the GUS staining solution. Marked differences in GUS activity were observed between the endogenous, and transformed tissue as the transformed plants exhibited a deep blue colour in reaction with Xgluc, while nontransformed plants only exhibited a pale blue coloration. Several factors such as of cocultivation period, preculture of explants, and acetosyringone-influenced GUS activity. Furthermore, in a comparative study, it was observed that GUS expression in leaf explants was more pronounced in the cut ends of the veins, whereas zygotic and somatic embryos, hypocotyls, and the adjacent region are the main target sites [27]. Recently, in another experiment, the expression of p35S. GUS expression was found to be stronger in the root tip and central vascular system compared to other regions in the root system [43].

Recently, the expression of both uidA and $g f p$ genes driven by the CaMV35S promoter was monitored using various Agrobacterium strains and culture conditions [37]. Expression of the sgfp-S65T gene driven by the CaMV35S promoter (signified by green fluorescence) was observed in cocultivated calli just 2 days after cocultivation. Initially, green fluorescence appeared as discrete spots but subsequently, calli that showed green fluorescence increased in size, producing a bright fluorescence mass after 15 days cocultivation. The expression of both uidA and sgfp was intense in globular- and torpedo-shaped embryos until the development of cotyledonary leaves. In older leaves, green florescence was weak due to the interference of chlorophyll, which emits red fluorescence at the same activating wavelength. The pattern of expression of GUS and $g f p$ genes driven by the CaMV35S promoter was similar, being much more pronounced in the leaf veins and root tips and in vascular zones. Using the CaMV35S promoter, similar expression patterns were obtained for DsRFP in somatic embryos [31] and for $g f p$ in roots [44].

\section{Transformation Systems}

Both direct and indirect DNA delivery systems have been employed to transform coffee by various workers and the details are described below.

\subsection{Direct DNA Delivery}

7.1.1. Electroporation. Electroporation is a process through which permeability of the cell plasma membrane is significantly increased by the external application of electrical field. It is usually used in molecular biology as a way of introducing some substance into a cell, such as a drug that can change the cell's function, or a piece of coding DNA. Electroporation was used to integrate foreign 


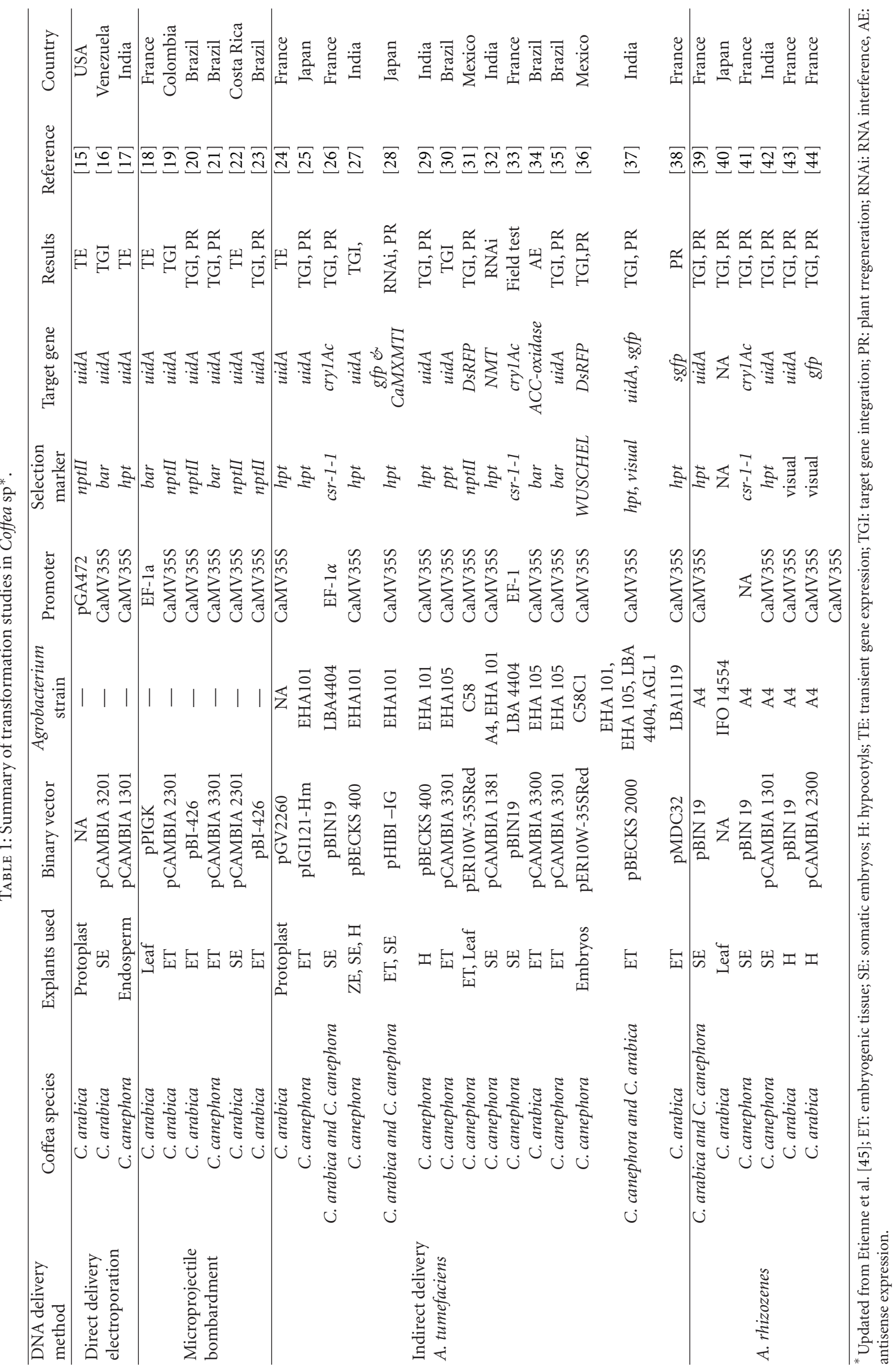


DNA into protoplasts of C. arabica [15]. Regeneration of transformed embryos and plantlets resistant to kanamycin was obtained but the plantlets did not survive due to a weak root system. In another experiment, various parameters influencing transformation of coffee somatic embryos using electroporation of pCAMBIA 3201 plasmid carrying the uidA gene were described [16]. The results showed that the electroporation of somatic embryos at torpedo stage can be a promising approach to coffee transformation since transformed torpedo-shaped embryos produced significantly higher numbers of gus positive secondary embryos in the culture medium. Recently, the expression of $u i d A$ gene driven by the N-methyltransferase (NMT) promoter was studied by electroporation of coffee endosperm [17]. The results indicated that uidA gene expression driven by the NMT promoter is targeted to the external surface of the vacuoles.

7.2. Microprojectile Bombardment. Genetic transformation of coffee via microprojectile bombardment was described for the first time, using a gunpowder driven device and several target explants [18]. The study compared different promoters and demonstrated that the EF- $1 \alpha$ promoter from Arabidopsis thaliana is more effective than the CaMV35S promoter in driving transient GUS expression in leaves of microcuttings. The interaction between osmotic preconditioning and physical parameters of helium gun device was studied in C. arabica suspension cells. It was observed that four hours of pretreatment of the target tissue with mannitol and sorbitol before bombardment increased the number of cells expressing GUS gene without causing cell necrosis [19].

Successful regeneration of transgenic coffee plants $(C$. canephora) by microprojectile bombardment was achieved by using the pCambia3301 plasmid containing the uidA and bar genes [21]. The study demonstrated the effectiveness of the bar gene for selection of transformants in vitro and in vivo identification of transgenic coffee plants. In C. arabica, the plasmid pBI-426 carrying the nptII and uidA genes was employed in particle bombardment of embryogenic calli, and transformants were selected using kanamycin [20]. The transgenic status of the regenerated plants was confirmed by PCR analysis. Recently, a C. arabica suspension culture with a high regenerative capacity for secondary somatic embryogenesis was used for transformation using microprojectile bombardment [22]. However, no transformants could be regenerated due to damage to bombarded tissue. Very recently, successful regeneration of transgenic C. arabica was reported using bombardment of embryogenic calli followed by kanamycin selection [23]. The authors reported the normal growth of the transgenic plants and obtained $\mathrm{T}_{1}$ progeny presenting $3: 1$ segregation of the uidA transgene.

7.3. Indirect DNA Delivery. Agrobacterium tumefaciens. The Agrobacterium tumefaciens mediated transformation technique has been extensively used for genetic transformation of coffee and is the method of choice for many workers (see Table 1). An initial report of A. tumefaciensmediated transformation of coffee involved the cocultivation of protoplast with different Agrobacterium strains carrying
nptII and uidA genes [24]. Transient GUS expression was demonstrated in the callus tissue derived from protoplasts but plant regeneration was not obtained. The first successful A. tumefaciens transformation and transgenic plant regeneration were achieved in C. canephora [25] and subsequently in C. arabica [26]. In C. canephora, various parameters that influence T-DNA delivery to coffee tissue were studied using transient GUS gene expression [27]. It was reported that preculture of explants prior to Agrobacterium cocultivation, addition of acetosyringone to cocultivation medium and the duration of the cocultivation period significantly influenced T-DNA delivery to coffee tissue. In addition to the culture conditions, the A. tumefaciens strains also influence the transformation efficiency in coffee [37]. A. tumefaciens strains and their plasmids are classified by the function of the opine genes they carry. These opines, which are synthesized in the infected plant cells, are mainly agropine, nopaline, and octopine. For coffee transformation, various A. tumefaciens strains such as LBA 4404 pAL4404 (octopine), C58CI pMP90 (nopaline), EHA 101 pEHA101 (agropine), EHA 105 pEHA101 (agropine), and AGL1 pTiBo542 (agropine) have been used by various workers (see Table 1). Recently, a study was carried out to compare the efficiency of four different Agrobacterium strains (LBA 4404, EHA101, EHA105, AGL1) in coffee transformation using pBECKS 2000 vector constructs carrying uidA and $g f p$ reporter genes [37]. It was observed that EHA 105 and EHA101 were more efficient compared to LBA4404 in T-DNA delivery and transgenic plant regeneration. Based on this improved protocol, mass production of transgenic coffee plants of both C. arabica and C. canephora was achieved [37].

In order to improve the efficiency of A. tumefaciens mediated transformation, sonication and vacuum infiltration methods were incorporated during cocultivation [31, 35]. In most of the A. tumefaciens mediated transformation, embryogenic tissues and/or somatic embryos were used as the target material for cocultivation (see Table 1). In $C$. canephora, a highly efficient $A$. tumefaciens transformation and regeneration protocol were established using hypocotyl explants as the target material (Figures 1(a)-1(1)) [29]. In C. canephora, the collar region of the hypocotyls was found to be more suitable for A. tumefaciens transformation [107]. However, in C. arabica, embryogenic calli were found to be more suitable for A. tumefaciens transformation [38]. The methodology for genetic transformation of Coffea using Agrobacterium was described in detail [108]. They were able to transform 20 different genotypes either belonging to $C$. arabica or $C$. canephora by cocultivation of embryogenic calli with $A$. tumefaciens.

A. tumefaciens mediated transformation has also been used for gene silencing using RNAi technology and several genes such as theobromine synthase (CaMXMTI) and Nmethyltransferase (NMT) (both involved in caffeine biosynthesis) and the ACC oxidase gene (involved in ethylene biosynthesis) were targeted to coffee tissue in reverse orientation for obtaining stable silencing [28, 32, 34]. Recently, transgenic C. canephora plants incorporating a homeobox gene WUSCHEL (WUS) responsible for stem cell identity were regenerated [36]. 


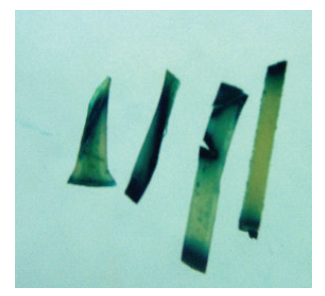

(a)

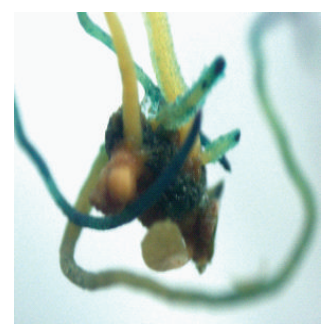

(f)

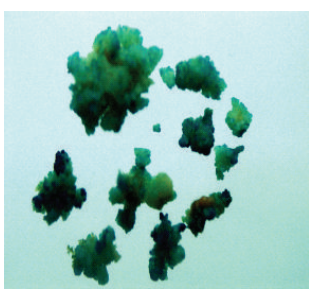

(b)

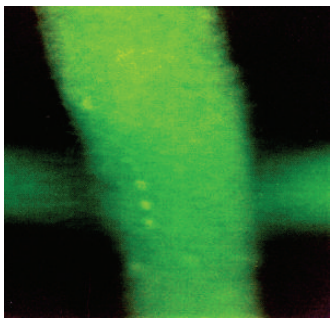

(g)

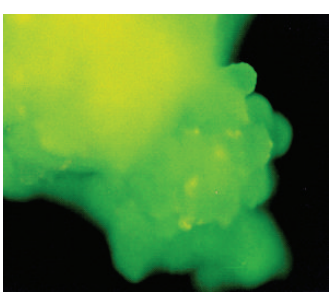

(c)

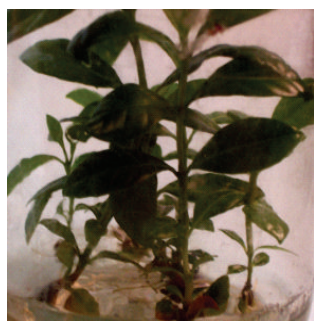

(h)

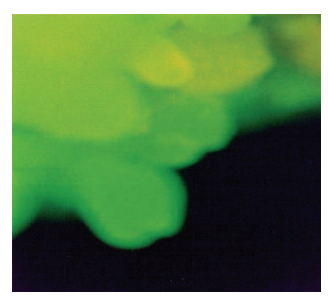

(d)

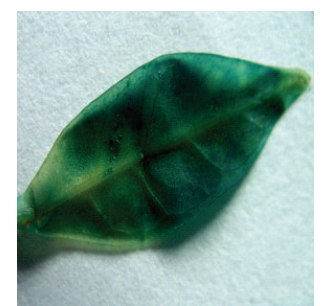

(i)

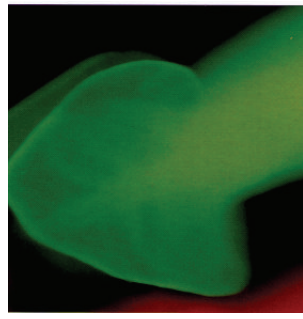

(e)

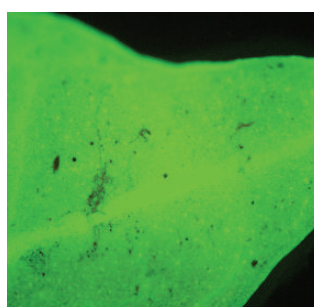

(j)

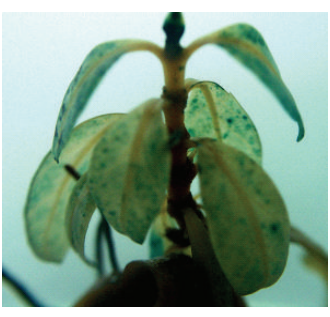

(k)

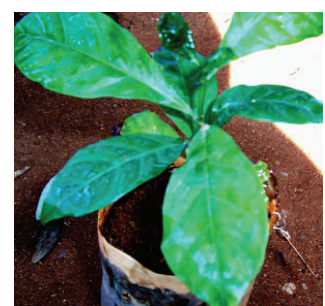

(1)

Figure 1: Agrobacterium tumefaciens mediated transformation and regeneration of C. canephora cv. C $\times \mathrm{R}$ and $C$. arabica genotypes. (b, c, d, $\mathrm{f}$, and k) C. arabica (a, e, g, h, i, j, and l) C. canephora. (a) Cocultivated hypocotyls of in vitro seedlings expressing transient GUS expression; (b) embryogenic calli showing transient GUS expression following cocultivation; (c) initiation of somatic embryos from the transformed calli showing green fluorescence; (d) mass of heart shaped somatic embryo showing green fluorescence; (e) germinating somatic embryo with well-developed cotyledon leaves with bright green fluorescence; (f) Gus expression in the root tips of a germinated transformed plant; (g) strong GFP expression in transgenic root; (h) in vitro plant regeneration; (i) Gus staining of the leaf of a transgenic plant; (j) GFP expression in the developing leaf; (k) GUS staining of the regenerated transformed plant; (1) transgenic plant in the soil.

Agrobacterium rhizogenes. Agrobacterium rhizogenes mediated transformation of both C. canephora and C. arabica species was reported as early as 1993 [39]. Subsequently, many workers have reported successful A. rhizogenes mediated transformation and plantlet regeneration in both $C$. arabica and C. canephora using different explants [40, 42, 44, 109]. In almost all cases, Agrobacterium strain A4 was used except in one case where bacterial strain IFO 14554 has been used (Table 1). Most of the binary constructs used in A. rhizogenes transformation are either based on a pBIN19 or $p$ Cambia backbone. A. rhizogenes transformation is very useful for functional analysis of genes involved in resistance to root knot nematode in coffee.

\section{Selection of Transformants}

The successful recovery of stable transformants depends upon the choice of a suitable selective agent, its optimal concentration, timing, and frequency of selection. An effective selective agent must allow the growth and development of transformed tissue but simultaneously restrict the proliferation of nontransformed cells in the same culture medium. Therefore, incorporation of the right selectable marker gene in gene constructs is critical to the success of transformation. In coffee transformation, various selection marker genes ( $h p t$ hygromycin-R, nptII kanamycin-R, csr1$I$ chlor and sulfuron-R, $p p t$ phosphinothricin-R) were used (Table 1), and their efficacy has been evaluated $[18,27]$. The first work in coffee transformation was carried out using kanamycin as the selective agent [39]. However, contradictory results were obtained with regard to the efficacy of kanamycin for selection of coffee transformants. Many workers $[15,39,41,110]$ have reported the development of nontransformed somatic embryos at higher kanamycin concentrations and have attributed this to a poor capacity for transformant selection. However, there have also been several reports of successful selection of transformed coffee plants using kanamycin as the sole selective agent $[20,23$, 31]. In many transformation experiments, hygromycin at concentrations of $20-100 \mathrm{mg} / \mathrm{L}$ was used successfully for selection of transformants [25, 27-29]. The efficiency of hygromycin as a selective agent was tested in different 
transformed and nontransformed tissue of C. canephora and it was observed that $25 \mathrm{mg} / \mathrm{L}$ hygromycin severely checked nontransformed somatic embryo growth and proliferation [27]. Similar results were also obtained by using hygromycin in A. rhizogenes mediated coffee transformation [42].

In addition to antibiotics, several other types of selection markers such as herbicide selection and positive selection have also been used in coffee transformation. The reliability of chlorsulfuron (csr1-I), phosphinothricin ( $p p t$ ), and ammonium glufosinate (bar) as selection markers to regenerate transformed tissue were already confirmed in both $C$. arabica and C. canephora using various transformation methods $[21,26,30]$. As an alternative to negative markers such as antibiotics and herbicides, positive selection marker genes such as phosphomannose isomerase ( $p m i$ ) and xylose isomerase ( $x y l A)$ have also been used for coffee transformation, producing transformants able to grow in the presence of mannose and xylose, respectively, without an additional carbohydrate source. The study indicated that compared to mannose, xylose is an effective selective agent for coffee transformation [111].

In recent times, transgenic crops regenerated carrying antibiotic and herbicide resistance genes have generated public disquiet about food safety and environmental impact. This has stimulated research into utilizing visual selection markers instead of using antibiotic and/or herbicide selection markers. In coffee, green fluorescent protein, $(g f p)$, and red fluorescent protein $(D s R F P)$ were used for visual selection of transformed tissue following A. tumefaciens mediated transformation $[28,31,37]$. The regeneration of transformed roots of $C$. arabica using visual selection of green epifluorescence without using any selective agent was achieved through A. rhizogenes mediated transformation [44]. Recently transgenic plants of both C. canephora and C. arabica were regenerated by employing visual selection of green fluorescent protein as the sole screen following $A$. tumefaciens mediated transformation [112].

\section{Transgene Expression}

9.1. Expression of Reporter Genes. Studies pertaining to expression of transgenes in a perennial crop like coffee are very important. However, such reports are very limited. The expression of uidA and $g f p$ transgenes driven by a CaMV35S viral promoter was monitored at different stages of plant growth of $C$. canephora following A. tumefaciens mediated transformation [27, 37]. It was observed that maximum expression of both uidA and $g f p$ genes were obtained at the globular- and torpedo-shaped somatic embryos. Following the development of cotyledon leaves, GUS expression was scattered, with pronounced expression shifted to vascular regions in the well-developed leaves. In roots, maximum expression was obtained in the root tips and root hairs compared to the main roots. Recently, the expression of uidA gene driven by the double CaMV35S promoter was monitored in the flowers and fruits of $C$. arabica transgenic plants obtained through microprojectile bombardment [23].
9.2. Expression of Insect Resistance Genes. Transgenic coffee (C. canephora) plants incorporating synthetic cry genes (cry1Ac) from Bacillus thuringiensis were regenerated [26]. Field assessment demonstrated the resistance of transgenic plants to coffee leaf miner (Perileucoptera coffeella) indicating the functional stability of the transgenes [33]. In another study, transgenic plants of $C$. canephora incorporating $\alpha$ A11 from common bean were produced via $A$. tumefaciens mediated transformation, and bioassays with the insect are underway to confirm functional validation of its protein in coffee [30].

9.3. Expression of Herbicide Resistance Genes. Transgenic coffee plants incorporating the csr-1-1 gene were produced using A. tumefaciens mediated transformation [26]. In this study, plants were selected using chlorsulfuron but several nontransformed escapes were obtained, which suggests that the herbicide is not a very tight selective agent. In another study, transgenic C. canephora plants were produced using the bar gene [35]. Regenerated plants were sprayed with the herbicide ammonium glufosinate under green house conditions and showed no phytotoxicity effects.

9.4. Modification of Expression of Genes Controlling Biochemical and Physiological Traits. The expression of genes, involved in the caffeine biosynthesis pathway, was modified using RNAi technology to reduce the level of CaMXMT1 (theobromine synthase) [28]. Transgenic plants expressing antisense ACC oxidase (involved in fruit maturation and ethylene production) have also been produced and stable expression of the transgene observed [34].

\section{Applications of Transgenic Technology}

Genetic transformation technology has potential applications in coffee agriculture by incorporating desirable traits such as disease and insect resistance, drought and frost, tolerance and herbicide resistance. Transgenic technology can also be used to increase nutritional value and improve cup quality, produce varieties with caffeine-free beans, and for production of hybrid crops for molecular farming. Identification of target specific genes is one of the prerequisites for developing transgenic crops. The availability of a large number of EST sequences in coffee and initiation of coffee genome sequencing may speed up the gene discovery and accelerate transgenic research efforts in coffee.

10.1. Insect Resistance. Production of insect resistant coffee plants is one of the major objectives of the breeding programs. The major pests attacking coffee include coffee berry borer (CBB, Hypothenemus hampei), white stem borer (WSB, Xylotrechus quadripes), leaf miner (Perileucoptera coffeela), and root nematodes (Meloidogyne spp. and Pratylenchus spp.). The CBB is present in almost all the coffee growing countries and considered to the most devastating pest in coffee. To date, there is no reported source of resistance to $\mathrm{CBB}$ in the coffee gene pool. Like CBB, WSB is another serious pest in arabica coffee in India and several other 
East Asian countries. Both CBB and WSB belong to the order Coleoptera. For India, controlling WSB is the biggest challenge and has therefore become the highest research priority. Robusta is generally resistant to WSB but the interspecific robusta arabica hybrids are susceptible to WSB. Although leaf miner is not yet a serious pest in India and other East Asian countries, it is an economically important pest in East Africa and Brazil.

Effective chemical control of CBB and WSB is difficult due to the nature of their life cycle inside the berry and stem, respectively, as well as environmental concern regarding the use of pesticides. Biological control measures are adapted to combat these insect pests with varying degrees of success. Developing coffee plants resistant to these pests using genetic transformation technology could be one of the alternative strategies to counter pest damage.

For insect resistance, several different classes of proteins from bacterial, plant, and animal sources have been isolated and their insecticidal properties tested against many important pests. Amongst these proteins, Bt toxins are most important and several transgenic crops expressing Bt genes have been commercialized. Coffee transgenic plants carrying a synthetic version of the cry $1 A c$ gene have been produced $[26,67]$. Indeed, this was the first report that an important agronomic trait has been introduced into a coffee plant. The transgenic plants presented similar features in growth and development compared to normal plants. Transgenic plants highly resistant to leaf minor under greenhouse conditions were tested under field conditions in French Guyana for 4 years for field resistance [33, 113]. From a total of 54 independent transformation events, $70 \%$ of the events were resistant to leaf minor. Unfortunately, the field trial was vandalized which led to the termination of the experiment [114].

The effectiveness of $B t$ genes in controlling coleopteran pests is well documented in corn and potato, which indicates that $\mathrm{Bt}$ genes might be effective against $\mathrm{CBB}$. The high toxicity of $B$. thuringiensis serovar israelensis against first instar larvae of CBB has been demonstrated [115]. In another experiment, an $\alpha$-amylase inhibitor from Phaseolus vulgaris was tested against CBB and found to have an inhibitory effect on its growth and development [116].

In addition to the CBB and WSB, arabica coffee varieties are also susceptible to endoparasitic root-knot nematode (Meloidogyne spp.) [117]. So far, 15 species have been reported to be parasites of coffee. Controlling nematodes is extremely difficult and currently seedling grafting with robusta rootstock is followed as one of the control measure. Sources of resistance specific to root-knot nematodes have been identified in coffee trees [118] and the Mex-1 gene conferring resistance to $M$. exigua in $C$. arabica is in the process of isolation [103]. The functional analysis of nematode resistant genes could be carried out by using the A. rhizogenes mediated transformation protocol already developed in coffee (See Table 1). Root-specific promoters could also be used in the vector constructs to drive transgene expression in the root.

Cultivation of insect resistant transgenic coffee should address ecological concerns related to insects and soil microorganisms. Transgene stability also needs to be studied since a coffee plantation can remain for several years without replantation. The constant selection pressure of the transgenic plants on the targeted insect population should be monitored, as there may be a chance of emergence of insect resistant populations.

10.2. Tolerance to Abiotic Stress. In many coffee growing countries, abiotic stress such as drought and frost are the major climatic factors that limit coffee production. Changes in climatic patterns due to global climate change is considered increasingly important for coffee cultivation. Drought induces water stress in plants, which affects vegetative growth and vigour, and triggers floral abnormalities and poor fruit set. It also indirectly increases the incidence of pests and diseases in the plants. Arabica is generally more tolerant to water stress than robusta, partly due to its extensive deep root system. C. racemosa is known to be a good source of drought tolerance. In India, hybrids between $C$. canephora and $C$. racemosa have been obtained and are currently under evaluation for drought tolerance.

In many coffee growing countries, coffee is propagated in marginal areas where the annual rainfall is below $1000 \mathrm{~mm}$, with prolonged dry spells of over 4-5 months. In those areas, water shortage and unfavourable temperatures constitute major constraints, and the growth and productivity of robusta coffee are badly affected.

As with drought, periodic frost also affects coffee production in parts of Brazil. The introduction of drought and frost tolerant genes through genetic transformation would be of great importance for alleviating these problems. Research is now being carried out by several groups to identify genes involved in biotic as well as abiotic stress. The most promising approach of genetic engineering for drought tolerance includes the use of functional or regulatory genes as well as the transfer of transcription factors. In recent years, plants tolerant to high temperature and water stress have been the subject of intense research [119-121]. For achieving drought tolerance, genes that have been targeted include those encoding enzymes involved in detoxification or osmotic response metabolism, enzymes active in signalling, proteins involved in the transport of metabolites, and regulating the plant energy status [119-121]. The dissection of molecular mechanisms related to signal transduction and transcriptional regulation might help in engineering drought tolerance in coffee.

10.3. Disease Resistance. Coffee leaf rust (CLR) caused by the fungus Hemileia vastatrix is the most important disease in coffee with substantial loss to coffee production and productivity in all the coffee growing countries. In addition to leaf rust, coffee berry disease (CBD) caused by fungus Colletotrichum kahawae can be a devastating anthracnose causing substantial crop loss in Africa. Several other fungal and bacterial diseases may also affect coffee, causing economic damage to a small extent. Arabica is more susceptible to many diseases than robusta coffee. Though most of the disease control measures rely upon chemical control, they are more expensive and labour intensive. The long-term solution 
is the breeding of resistant varieties, which is the focus of many breeding programmes. However, breeding for disease resistant varieties is time consuming due to the perennial nature of coffee, with its long gestation period. India has a long history of arabica coffee breeding especially for leaf rust resistance and is the first country to demonstrate the existence of multiple races of leaf rust. Resistance to CLR is conditioned primarily by a number of major $\left(S_{H}\right)$ genes, and coffee genotypes are classified into different resistance groups based on their interaction with different rust races pathogen [122]. Currently C. canephora provides the main source of resistance to pests and diseases including CLR $(H$. vastatrix) and $\mathrm{CBD}$ (C. kahawae) and is therefore used in breeding programs. Other diploid species like C. liberica and C. racemosa have been used as a source of resistance to coffee leaf rust and coffee leaf miner, respectively $[12,123]$.

The development of coffee varieties resistant to major fungal diseases such as CLR and CBD using transgenic technology will benefit the coffee industry immensely. During the last 15 years, significant progress has been made in the area of host-pathogen interactions [124, 125] and many resistance genes involved in recognizing invading pathogens have been identified and cloned [126]. A number of signalling pathways, which are induced following pathogen infection, have been dissected [127]. Many antifungal compounds that are synthesized by plants to combat fungal infection have been identified [128]. Understanding the specific induction of targeted pathways and identification of specific pathways responsible for particular fungal resistance is important in order to employ this strategy in transgenic technology. The recent investigation of gene expression during coffee leaf rust infection could give an insight into the defence pathways operating in coffee $[129,130]$.

Efforts have been made to identify and clone resistance genes from coffee for achieving durable resistance. Recently, the genetic and physical map of two resistance genes, that is, the $S_{H} 3$ gene conferring resistance to rust [104] and the $C k 1$ gene conferring resistance to C. kahawae CBD [105] have been established. These genes could be used for molecular marker assisted breeding programmes.

10.4. Production of Low-Caffeine Coffee. Low-caffeine and decaffeinated coffee represent around $10 \%$ of the coffee sales around the world [35]. The industrial process for coffee decaffeination can be expensive and affects the original flavour and aroma in coffee [131].

Transgenic coffee plants with suppressed caffeine synthesis using RNA interference (RNAi) technology have been obtained $[28,106]$. Specific sequences in the $3^{\prime}$ untranslated region of the theobromine synthase gene (CaMXMT1) were selected for construction of RNAi short and long fragments. The caffeine and theobromine content of the transgenic plants reduced by up to $70 \%$ compared to the untransformed plants. In C. canephora, RNAi technology has also been employed to silence the $\mathrm{N}$-methyl transferase gene involved in caffeine biosynthesis [17]. Recently the promoter of an N-methyltransferase (NMT) gene involved in caffeine biosynthesis was cloned [100], which will be very useful for studying the regulation of caffeine biosynthesis.
10.5. Improvement in Cup Quality. Improvement in coffee cup quality requires elaborate knowledge of the chemical constituents as well as the metabolic pathways involved in the elaboration of quality. The constituents of coffee beans include minerals, proteins, carbohydrates caffeine, chlorogenic acids (CGA), glycosides, lipids, and many volatile compounds that give flavour to coffee by roasting. Among these, the role of three major constituents: sucrose, CGA, and trigonelline have been studied in coffee. The sucrose content of coffee bean is associated with coffee flavour; the higher the sucrose content in green beans, the more intense will be the cup flavour $[132,133]$. The sucrose content of $C$. arabica $(8.2-8.3 \%)$ is higher than C. canephora (3.3-4.0\%). The sucrose:amino acids ratio in green beans determines the profile of volatile compounds. Manipulating sucrose content in coffee bean is therefore important in improving cup quality. Recently, the sucrose synthase gene (CcSUS2) from C. canephora has been cloned and sequenced [66]. This provides an opportunity to manipulate the sucrose content in coffee.

Chlorogenic acids are products of phenylpropanoid metabolism. Chlorogenic acids are a group of hydroxycinnamoyl quinic acids (HQA) formed by esterification between caffeic acids, coumaric acids, and quinic acids [134]. They are present in relatively large quantities in the coffee bean and are the precursor of phenolic compounds in roasted beans. Robusta beans contain higher CGA (10\%) compared to arabica beans (6-7\%). CGA are known to have antioxidant properties as well as being associated with disease resistance [135]. Genetic manipulation of genes involved in CGA synthesis can serve either of these purposes by up- or downregulating the pathway.

Phenylalanine ammonia-lyase (PAL) catalyzes the first step of the phenylpropanoid pathway leading to the synthesis of a wide range of chemical compounds including flavonoids, coumarins, hydroxycinnamoyl esters, and lignins [136]. Recently, the full length cDNA and corresponding genomic sequences of PAL from C. canephora was isolated, characterized, and functionally validated $[137,138]$. This has opened up new possibilities for manipulating the level of the PAL enzyme in coffee which in turn will be useful for cup quality improvement and manipulating antioxidant properties in coffee.

10.6. Fruit Ripening. Uniformity during fruit ripening is decisively related to cup quality in coffee, and consequently to the value of the product. Fruits at the ideal ripening stage produce the best organoleptic characteristics for coffee. The presence of overripened or green fruits changes the acidity, the bitterness and consequently the cup quality. In order to maximise uniform ripening of coffee fruits, it is essential to control the action of genes involved in the last step of maturation process. Ethylene is known to trigger ripening, and increasing ethylene biosynthesis is associated with various stages of ripening process [139]. To control coffee fruit maturation, two of the major genes involved in ethylene biosynthesis, namely, ACC synthase and ACC oxidase, have been cloned $[139,140]$. Introduction of the ACC oxidase gene in antisense orientation has been achieved 
in both C. arabica and C. canephora [34]. The effect of the transgene on ethylene production and fruit maturation has yet to be reported. The inhibition of genes downstream to the initial ethylene burst is also an option to control coffee fruit maturation [141].

\section{GM Coffee and Consumer Approval}

Considering that the technology for coffee transformation is available, and given the rapid progress in gene discovery, it may not be very long before transgenic coffee hits the market. Since transgenic coffee is at the initial stages of commercial development and needs to be integrated into the main breeding programmes for evaluation, it will take at least 15-20 years for field release of GM coffee. However, the main obstacle will be consumer approval and acceptance of genetically modified coffee. With a rapid increase in the cultivation of various transgenic crops around the globe, consumer perception towards transgenic coffee may be more positive than it is today. Undoubtedly, GM coffee must undergo rigorous testing on both health and environmental effects before it is released for commercial cultivation.

\section{Conclusion and Future Perspectives}

During the last 15 years, transgenic crops became an integral part of the agricultural landscape. The number of transgenic crops and the area under cultivation is rapidly increasing in many parts of the world. This has been made possible by the application of genetic transformation technology and its integration with plant breeding programmes. Despite significant advances made over the last 15 years, coffee transformation is still time consuming and laborious. In addition, a genotype independent transformation protocol is not yet achieved in coffee. Genetic transformation of coffee has two major applications: (1) a tool for the validation of gene function and (2) production of transgenic crops with agronomically important traits. In order to achieve these goals, a simple, efficient, genotype-independent routine transformation protocol needs to be developed for coffee. Public concern regarding the use of antibiotic marker genes in transgenic technology need to be addressed. In this regard, coffee transformation should be based on several strategies such as use of positive selection markers and GFP for transformant selection, and on the cre/lox system for elimination of selectable marker genes. Development of a clean gene transgenic technology for coffee based on the gfp gene for visual selection and the cre/lox vector system is currently in progress. All coffee transformation programs should address the expression of transgenes in appropriate tissues, for which tissue specific promoters need to be used. The stable expression of transgenes should be monitored at every stage of plant growth and development. In addition, genomic technologies such as transgenics, molecular marker assisted breeding, genomics, proteomics, and metabolomics should complement traditional breeding efforts for hastening the genetic improvement of coffee.

Further coffee transformation programmes and investments should involve public and private companies. At the same time, researchers must make an effort to educate the public and help them understand the real advantages and risks associated with the use of genetically modified coffee. This is the only way to address irrational fears about the transgenic crops, and this will pave the way to the use of transgenic technology for coffee improvement.

\section{Acknowledgments}

M. K. Mishra thanks the Department of Biotechnology, Government of India for an overseas Associateship to De Montfort University, UK and Coffee Board, India for deputation.

\section{References}

[1] ICO. International Coffee Organization, "ICO Annual Review 2010," 2010, http://www.ico.org/.

[2] A. P. Davis, R. Govaerts, D. M. Bridson, and P. Stoffelen, "An annotated taxonomic conspectus of the genus Coffea (Rubiaceae)," Botanical Journal of the Linnean Society, vol. 152, no. 4, pp. 465-512, 2006.

[3] A. Charrier and J. Berthaud, "Botanical classification of coffee," in Coffee, Botany, Biochemistry and Production of Beans and Beverage, M. N. Clifford and K. C. Wilson, Eds., pp. 13-47, Croom Helm, London, UK, 1985.

[4] A. Lécolier, P. Besse, A. Charrier, T. N. Tchakaloff, and M. Noirot, "Unraveling the origin of Coffea arabica "Bourbon pointu" from la Réunion: a historical and scientific perspective," Euphytica, vol. 168, no. 1, pp. 1-10, 2009.

[5] T. W. M. Gole, T. Demel, M. Denich, and T. Bosch, "Diversity of traditional coffee production systems in Ethiopia and their contribution to conservation of genetic diversity," in Proceedings of the International Agricultural Research for Development, Deutscher Tropentag, Bonn, Germany, 2001.

[6] A. S. Thomas, "The wild arabica coffee on the Boma plateau of Anglo-Egyptian Sudan," Empirical Journal of Experimental Agriculture, vol. 10, pp. 207-212, 1942.

[7] F. Anthony, J. Berthaud, J. L. Guillaumet, and M. Lourd, "Collecting wild coffee species in Kenya and Tanzania," Plant Genetic Resources Newsletter, vol. 69, pp. 23-29, 1987.

[8] E. W. Githae, M. Chuah-Petiot, J. K. Mworia, and D. W. Odee, "A botanical inventory and diversity assessment of Mt. Marsabit forest, a sub-humid montane forest in the arid lands of Northern Kenya," African Journal of Ecology, vol. 46, no. 1, pp. 39-45, 2008.

[9] M. F. Carneiro, "Coffee biotechnology and its application in genetic transformation," Euphytica, vol. 96, no. 1, pp. 167$172,1997$.

[10] H. A. M. van der Vossen, "Coffee selection and breeding," in Coffee: Botany, Biochemistry and Production of Beans and Beverage, M. N. Clifford and K. C. Wilson, Eds., pp. 48-96, Croom Helm, London, UK, 1985.

[11] K. H. Srinivasan and R. L. Narasimhaswamy, "A review of coffee breeding work done at the Government coffee experiment station, Balehonnur," Indian Coffee, vol. 34, pp. 311-321, 1975.

[12] O. Guerreiro Filho, M. B. Silvarolla, and A. B. Eskes, "Expression and mode of inheritance of resistance in coffee to leaf miner Perileucoptera coffeella," Euphytica, vol. 105, no. 1, pp. 7-15, 1999. 
[13] A. Bettencourt, Considerações gerais sobre o 'Híbrido de Timor', Instituto Agronomico de Campinas. Circular, no. 31, Instituto Agronomico de Campinas, 1973.

[14] "Coffee Guide," Central Coffee Research Institute, Coffee Board, Bangalore, India, 2000.

[15] C. R. Barton, T. L. Adams, and M. A. Zarowitz, "Stable transformation of foreign DNA into Coffea arabica plants," in Proceedings of the 14th International Conference on Coffee Science (ASIC '91), pp. 460-464, San Francisco, Calif, USA, 1991.

[16] R. Fernandez-Da Silva and A. Menéndez-Yuffá, “Transient gene expression in secondary somatic embryos from coffee tissues electroporated with the genes GUS and BAR," Electronic Journal of Biotechnology, vol. 6, no. 1, pp. 29-35, 2003.

[17] V. Kumar, K. V. Satyanarayana, A. Ramakrishna, A. Chandrashekar, and G. A. Ravishankar, "Evidence for localization of $N$-methyltransferase (MMT) of caffeine biosynthetic pathway in vacuolar surface of Coffea canephora endosperm elucidated through localization of GUS reporter gene driven by NMT promoter," Current Science, vol. 93, no. 3, pp. 383386, 2007.

[18] J. van Boxtel, M. Berthouly, C. Carasco, M. Dufour, and A. Eskes, "Transient expression of beta-glucuronidase following biolistic delivery of foreign DNA into coffee tissues," Plant Cell Reports, vol. 14, no. 12, pp. 748-752, 1995.

[19] A. G. Rosillo, J. R. Acuna, A. L. Gaitan, and M. de Pena, "Optimised DNA delivery into Coffea arabica suspension culture cells by particle bombardment," Plant Cell, Tissue and Organ Culture, vol. 74, no. 1, pp. 45-49, 2003.

[20] W. G. Cunha, F. R. B. Machado, G. R. Vianna, J. B. Teixeira, and E. V. S. Albuquerque, Obtencao De Coffea Arabica Geneticamente Modificadas Por Bombardmento De Calos Embriogenecos, vol. 73 of Boletim de Pesquisa e desenvolvimento, Embrapa, Brasilia, Brazil, 2004.

[21] A. F. Ribas, A. K. Kobayashi, L. F. P. Pereira, and L. G. E. Vieira, "Genetic transformation of Coffea canephora by particle bombardment," Biologia Plantarum, vol. 49, no. 4, pp. 493-497, 2005.

[22] A. M. Gatica-Arias, G. Arrieta-Espinoza, and A. M. Espinoza Esquivel, "Plant regeneration via indirect somatic embryogenesis and optimisation of genetic transformation in Coffea arabica L. cvs. Caturra and Catuaí," Electronic Journal of Biotechnology, vol. 11, no. 1, pp. 1-11, 2008.

[23] E. V. S. Albuquerque, W. G. Cunha, A. E. A. D. Barbosa et al., "Transgenic coffee fruits from Coffea arabica genetically modified by bombardment," In Vitro Cellular \& Developmental Biology - Plant, vol. 45, no. 5, pp. 532-539, 2009.

[24] J. Spiral and V. Petiard, "Protoplast culture and regeneration in coffee species," in Proceedings of the 14th International Conference on Coffee Science (ASIC '91), pp. 383-391, San Francisco, Calif, USA, 1991.

[25] T. Hatanaka, Y. E. Choi, T. Kusano, and H. Sano, "Transgenic plants of coffee Coffea canephora from embryogenic callus via Agrobacterium tumefaciens-mediated transformation," Plant Cell Reports, vol. 19, no. 2, pp. 106-110, 1999.

[26] T. Leroy, A. M. Henry, M. Royer et al., "Genetically modified coffee plants expressing the Bacillus thuringiensiscrylAc gene for resistance to leaf miner," Plant Cell Reports, vol. 19, no. 4, pp. 382-389, 2000.

[27] M. K. Mishra, H. L. Sreenath, and C. S. Srinivasan, "Agrobacterium-mediated transformation of coffee: an assessment of factors affecting gene transfer efficiency," in Proceedings of the 15th Plantation Crops Symposium, K. Sreedharan, P. K.
V. Kumar, Jayarama, and B. M. Chulaki, Eds., pp. 251-255, Mysore, India, December 2002.

[28] S. Ogita, H. Uefuji, M. Morimoto, and H. Sano, "Application of RNAi to confirm theobromine as the major intermediate for caffeine biosynthesis in coffee plants with potential for construction of decaffeinated varieties," Plant Molecular Biology, vol. 54, no. 6, pp. 931-941, 2004.

[29] M. K. Mishra and H. L. Sreenath, "High-efficiency Agrobacterium-mediated transformation of coffee (Coffea canephora Pierre ex. Frohner) using hypocotyl explants," in Proceedings of the 20th International Conference on Coffee Science (ASIC '04), pp. 792-796, Bangalore, India, October 2004.

[30] A. R. R. Cruz, A. L. D. Paixao, F. R. Machado et al., Obtencao de plantas transformadas de Coffea canephora por co-cultivo de calos embriogenicos com A. Tumefaciens, vol. 73 of Boletim de pesquiza e Desenvolvimento, Embrapa, Brasilia, Brazil, 2004.

[31] R. L. R. Canche-Moo, A. Ku-Gonzalez, C. Burgeff, V. M. Loyola-Vargas, L. C. Rodríguez-Zapata, and E. Castaño, "Genetic transformation of Coffea canephora by vacuum infiltration," Plant Cell, Tissue and Organ Culture, vol. 84, no. 3, pp. 373-377, 2006.

[32] V. Kumar, K. V. Sathyanarayana, S. Saarala Itty, P. Giridhar, A. Chandrasekhar, and G. A. Ravishankar, "Post transcriptional gene silencing for down regulating caffeine biosynthesis in Coffea canephora P. ex Fr," in Proceedings of the 20th International Conference on Coffee Science (ASIC '04), pp. 769-774, Bangalore, India, 2004.

[33] B. Perthuis, J. L. Pradon, C. Montagnon, M. Dufour, and T. Leroy, "Stable resistance against the leaf miner Leucoptera coffeella expressed by genetically transformed Coffea canephora in a pluriannual field experiment in French Guiana," Euphytica, vol. 144, no. 3, pp. 321-329, 2005.

[34] A. F. Ribas, R. M. Galvao, L. F. P. Pereira, and L. G. E. Vieira, "Transformacao de Coffea arabica com o gene da ACC oxidase em orientacao antinsenso," in Proceedings of the 50th Congreso Brasileiro de Genetica, p. 492, Sao Pulo, Brazil, September 2005.

[35] A. F. Ribas, A. K. Kobayashi, L. F. P. Pereira, and L. G. E. Vieira, "Production of herbicide-resistant coffee plants (Coffea canephora P.) via Agrobacterium tumefaciens-mediated transformation," Brazilian Archives of Biology and Technology, vol. 49, no. 1, pp. 11-19, 2006.

[36] A. Arroyo-Herrera, A. Ku Gonzalez, R. Canche Moo et al., "Expression of WUSCHEL in Coffea canephora causes ectopic morphogenesis and increases somatic embryogenesis," Plant Cell, Tissue and Organ Culture, vol. 94, no. 2, pp. 171-180, 2008.

[37] M. K. Mishra, H. L. Sreenath, Jayarama et al., "Two critical factors: Agrobacterium strain and antibiotics selection regime improve the production of transgenic coffee plants," in Proceedings of the 22nd International Association for Coffee Science (ASIC '08), pp. 843-850, Campinas, Brazil, 2008.

[38] A. F. Ribas, E. Dechamp, A. Champion et al., "Agrobacteriummediated genetic transformation of Coffea arabica (L.) is greatly enhanced by using established embryogenic callus cultures," BMC Plant Biology, vol. 11, article 92, 2011.

[39] J. Spiral, C. Thierry, M. Paillard, and V. Petiard, "Obtention de plantules de Coffea canephora Pierre (Robusta) transformées par Agrobacterium rhizogenes," Comptes Rendus de l' Academie des Sciences de Paris, vol. 316, no. 1, pp. 1-6, 1993.

[40] M. Sugiyama, C. Matsuoka, and T. Takagi, "Transformation of Coffea with Agrobacterium rhizogenes," in Proceedings of the 
16th International Conference on Coffee Science (ASIC '95), pp. 853-859, Kyoto, Japan, 1995.

[41] C. A. Giménez, A. Menéndez-Yuffá, and E. de García, "Efecto del antibiótico kanamicina sobre diferentes explantes del híbrido de café (Coffea sp.) Catimor," Phyton, vol. 59, pp. 3946, 1996.

[42] V. Kumar, K. V. Satyanarayana, S. Sarala Itty et al., "Stable transformation and direct regeneration in Coffea canephora $\mathrm{P}$ ex. Fr. by Agrobacterium rhizogenes mediated transformation without hairy-root phenotype," Plant Cell Reports, vol. 25, no. 3, pp. 214-222, 2006.

[43] E. Alpizar, E. Dechamp, B. Bertrand, P. Lashermes, and H. Etienne, "Transgenic roots for functional genomics of coffee resistance genes to root-knot nematodes," in Proceedings of the 21st International Conference on Coffee Science (ASIC '06), pp. 653-659, Montpellier, France, September 2006.

[44] E. Alpizar, E. Dechamp, S. Espeout et al., "Efficient production of Agrobacterium rhizogenes-transformed roots and composite plants for studying gene expression in coffee roots," Plant Cell Reports, vol. 25, no. 9, pp. 959-967, 2006.

[45] H. Etienne, P. Lashermes, A. Menendez-Yuffa, Z. de Guglielmo-Croquer, E. Alpizar, and H. L. Sreenath, "Coffee," in Compendium of Transgenic Crop Plants, Transgenic Plantation Crops, Ornamentals and Turf Grasses, C. Kole and T. Hall, Eds., pp. 57-84, Wiley Blackwell Publishers, London, UK, 2008.

[46] M. C. Combes, S. Andrzejewski, F. Anthony et al., "Characterization of microsatellite loci in Coffea arabica and related coffee species," Molecular Ecology, vol. 9, no. 8, pp. 11781180, 2000.

[47] D. L. Steiger, C. Nagai, P. H. Moore, C. W. Morden, R. V. Osgood, and R. Ming, "AFLP analysis of genetic diversity within and among Coffea arabica cultivars," Theoretical and Applied Genetics, vol. 105, no. 2-3, pp. 209-215, 2002.

[48] L. E. C. Diniz, N. S. Sakiyama, P. Lashermes, E. T. Caixeta, A. C. B. Oliveira, Zambolim et al., "Analysis of AFLP marker associated to the Mex-1 resistance locus in Icatu progenies," Crop Breeding and Applied Biotechnology, vol. 5, pp. 387-393, 2005.

[49] M. P. Maluf, M. Silvestrini, L. M. C. Ruggiero, O. Guerreiro Filho, and C. A. Colombo, "Genetic diversity of Coffea arabica inbreed lines assessed by RAPD, AFLP and SSR marker system," Scientia Agricola, vol. 62, no. 4, pp. 366-373, 2005.

[50] P. S. Hendre, R. Phanindranath, V. Annapurna, A. Lalremruata, and R. K. Aggarwal, "Development of new genomic microsatellite markers from robusta coffee (Coffea canephora Pierre ex A. Froehner) showing broad cross-species transferability and utility in genetic studies," BMC Plant Biology, vol. 8 , article 51, 2008.

[51] R. F. Missio, E. T. Caixeta, E. M. Zambolim, L. Zambolim, C. D. Cruz, and N. S. Sakiyama, "Polymorphic information content of SSR markers for Coffea spp," Crop Breeding and Applied Biotechnology, vol. 10, no. 1, pp. 89-94, 2010.

[52] P. Tornincasa, R. Dreos, B. de Nardi, E. Asquini, J. Devasia, M. K. Mishra et al., "Genetic diversity of commercial coffee (C. arabica $\mathrm{L}$ ) from America, India and Africa assessed by simple sequence repeats (SSRs)," in Proceedings of the 21st International Association for Coffee Science (ASIC '06), pp. 778-785, Montpellier, France, 2006.

[53] M. K. Mishra, S. Nishani, and Jayarama, "Genetic relationship among indigenous coffee species from India using
RAPD, ISSR and SRAP markers," Biharean Biologists, vol. 5, no. 1, pp. 17-24, 2011.

[54] M. K. Mishra, S. Nishani, and Jayarama, "Molecular identification and genetic relationships among coffee species (Coffea L.) inferred from ISSR and SRAP marker analyses," Archives of Biological Sciences, vol. 63, no. 3, pp. 667-679, 2011.

[55] M. K. Mishra, N. Suresh, A. M. Bhat et al., "Genetic molecular analysis of Coffea arabica (Rubiaceae) hybrids using SRAP markers," Revista de Biologia Tropical, vol. 59, no. 2, pp. 607-617, 2011.

[56] M. K. Mishra, A. M. Bhat, N. Suresh et al., "Molecular genetic analysis of arabica coffee hybrids using SRAP marker approach," Journal of Plantation Crops, vol. 39, no. 1, pp. 4147, 2011.

[57] M. K. Mishra, P. Tornincasa, B. de Nardi, E. Asquini, R. Dreos, L. Del Terra et al., "Genome organization in coffee as revealed by EST PCRRFLP, SNPs and SSR analysis," Journal of Crop Science and Biotechnology, vol. 14, no. 1, pp. 25-37, 2011.

[58] M. T. Gil-Agusti, N. Campostrini, L. Zolla, C. Ciambella, C. Invernizzi, and P. G. Righetti, "Two-dimensional mapping as a tool for classification of green coffee bean species," Proteomics, vol. 5, no. 3, pp. 710-718, 2005.

[59] P. S. Hendre, R. K. Aggarwal, and D. N. A. Markers, "Development and applications for genetic improvement of coffee," in Genomics Assisted Crop Improvement, R. K. Varshney and R. Tuberosa, Eds., vol. 2 of Genomics Application in Crops, pp. 399-434, Springer.

[60] M. de Block, L. Herrera-Estrella, M. van Montagu, J. Schell, and P. Zambryski, "Expression of foreign genes in regenerated plants and in their progeny," The EMBO Journal, vol. 3, no. 8, pp. 1681-1689, 1984.

[61] G. Y. Zhong, "Genetic issues and pitfalls in transgenic plant breeding," Euphytica, vol. 118, no. 2, pp. 137-144, 2001.

[62] A. Pallavicini, L. Del Terra, M. R. Sondahl et al., "Transcriptomics of resistance response in Coffea arabica L," in Proceedings of the 20th International conference on coffee science (ASIC '04), pp. 66-67, Bangalore, India, October 2004.

[63] C. Lin, L. A. Mueller, J. M. Carthy, D. Crouzillat, V. Pétiard, and S. D. Tanksley, "Coffee and tomato share common gene repertoires as revealed by deep sequencing of seed and cherry transcripts," Theoretical and Applied Genetics, vol. 112, no. 1, pp. 114-130, 2005.

[64] L. G. E. Vieira, A. C. Andrade, C. Colombo et al., "Brazillian coffee genome project: an EST-based genomic resource," Brazillian Journal of Plant Physiology, vol. 18, no. 1, pp. 95108, 2006.

[65] S. Noir, S. Patheyron, M. C. Combes, P. Lashermes, and B. Chalhoub, "Construction and characterisation of a BAC library for genome analysis of the allotetraploid coffee species (Coffea arabica L.)," Theoretical and Applied Genetics, vol. 109, no. 1, pp. 225-230, 2004.

[66] T. Leroy, P. Marraccini, M. Dufour et al., "Construction and characterization of a Coffea canephora BAC library to study the organization of sucrose biosynthesis genes," Theoretical and Applied Genetics, vol. 111, no. 6, pp. 1032-1041, 2005.

[67] J. Spiral, T. Leroy, M. Paillard, and V. Petiard, "Transgenic coffee (Coffea sp.)," in Biotechnology in Agricultulture and Forestry, Y. P. S. Bajaj, Ed., pp. 55-76, Springer, Heidelberg, Germany, 1999.

[68] M. F. Carneiro, "Advances in coffee biotechnology," AgBiotechNet, vol. 1, pp. 1-14, 1999. 
[69] V. Kumar, M. M. Naidu, and G. A. Ravishankar, "Developments in coffee biotechnology-in vitro plant propagation and crop improvement," Plant Cell, Tissue and Organ Culture, vol. 87, no. 1, pp. 49-65, 2006.

[70] G. Staritsky, "Embryoid formation in callus tissues of coffee," Acta Botanica Neerlandica, vol. 19, pp. 509-514, 1970.

[71] W. R. Sharp, L. S. Caldas, O. J. Crocomo, L. C. Monaco, and A. Carvalho, "Production of Coffea arabica callus of three ploidy levels and subsequent morphogenesis," Phyton, vol. 31, pp. 67-74, 1973.

[72] M. R. Sondahl and W. Sharp, "High frequency induction of somatic embryos in cultured leaf explants of Coffea arabica L," Zeitschrift für Pflanzenphysiologie, vol. 81, pp. 395-408, 1977.

[73] M. R. Sondahl, D. Spahlinger, and W. R. Sharp, "A histological study of high frequency and low frequency induction of somatic embryos in cultured leaf explants of Coffea arabica L," Zeitschrift für Pflanzenphysiologie, vol. 94, no. 2, pp. 101108, 1979.

[74] F. R. Quiroz-Figueroa, C. F. J. Fuentes-Cerda, R. RojasHerrera, and V. M. Loyola-Vargas, "Histological studies on the developmental stages and differentiation of two different somatic embryogenesis systems of Coffea arabica," Plant Cell Reports, vol. 20, no. 12, pp. 1141-1149, 2002.

[75] F. R. Quiroz-Figueroa, M. Méndez-Zeel, F. Sánchez-Teyer, R. Rojas-Herrera, and V. M. Loyola-Vargas, "Differential gene expression in embryogenic and non-embryogenic clusters from cell suspension cultures of Coffea arabica," Journal of Plant Physiology, vol. 159, no. 11, pp. 1267-1270, 2002.

[76] F. R. Quiroz-Figueroa, M. Méndez-Zeel, A. Larqué-Saavedra, and V. M. Loyola-Vargas, "Picomolar concentrations of salicylates induce cellular growth and enhance somatic embryogenesis in Coffea arabica tissue culture," Plant Cell Reports, vol. 20, no. 8, pp. 679-684, 2001.

[77] P. Giridhar, E. P. Indu, G. A. Ravishankar, and A. Chandrasekar, "Influence of triacontanol on somatic embryogenesis in Coffea arabica L. and Coffea canephora P. ex Fr," In Vitro Cellular \& Developmental Biology_Plant, vol. 40, no. 2, pp. 200-203, 2004.

[78] P. Giridhar, E. P. Indu, K. Vinod, A. Chandrashekar, and G. A. Ravishankar, "Direct somatic embryogenesis from Coffea arabica L. and Coffea canephora P ex Fr. under the influence of ethylene action inhibitor-silver nitrate," Acta Physiologiae Plantarum, vol. 26, no. 3, pp. 299-305, 2004.

[79] P. Giridhar, V. Kumar, E. P. Indu, A. Chandrasekar, and G. A. Ravishankar, "Thidiazuron induced somatic embryogenesis in Coffea arabica L. and Coffea canephora P ex Fr," Acta Botanica Croatica, vol. 63, no. 1, pp. 25-33, 2004.

[80] V. Kumar, P. Giridhar, A. Chandrashekar, and G. A. Ravishankar, "Polyamines influence morphogenesis and caffeine biosynthesis in in vitro cultures of Coffea canephora P. ex Fr," Acta Physiologiae Plantarum, vol. 30, no. 2, pp. 217-223, 2008.

[81] A. Ramakrishna, P. Giridhar, M. Jobin, C. S. Paulose, and G. A. Ravishankar, "Indoleamines and calcium enhance somatic embryogenesis in Coffea canephora P ex Fr," Plant Cell, Tissue and Organ Culture, vol. 108, no. 2, pp. 267-278, 2012.

[82] T. Hatanaka, E. Sawabe, T. Azuma, N. Uchida, and T. Yasuda, "The role of ethylene in somatic embryogenesis from leaf discs of Coffea canephora," Plant Science, vol. 107, no. 2, pp. 199-204, 1995.

[83] M. de Feria, E. Jiménez, R. Barbón, A. Capote, M. Chávez, and E. Quiala, "Effect of dissolved oxygen concentration on differentiation of somatic embryos of Coffea arabica cv.
Catimor 9722," Plant Cell, Tissue and Organ Culture, vol. 72, no. 1, pp. 1-6, 2003.

[84] A. Zamarripa, J. P. Ducos, H. Tessereau, H. Bollon, A. B. Eskes, and V. Pétiard, "Développement d'un procédé demultiplication en masse du caféier par embryogenèse somatique en milieu liquide," in Proceedings of the 14th International Scientific Colloquium on Coffee (ASIC '91), pp. 392-402, San Francisco, Calif, USA, 1991.

[85] A. Zamarripa, Etude et development de l'embryogenese en millieu liquid du cafeier (Coffea canephora P., Coffea arabica L. Et Hybrid Arabusta) [Ph.D. thesis], Ecolo National Superieure Agronomique, Rennes, France, 1993.

[86] J. P. Ducos, A. Zamarripa, A. B. Eskes, and V. Petiard, "Production of somatic embryos of coffee in a bioreactor," in Proceedings of the 15th International Conference on Coffee Science (ASIC '93), pp. 89-96, Montpellier, France, 1993.

[87] C. Noega and M. R. Sondahl, "Arabica coffee micropropagation through somatic embryogenesis via bioreactors," in Proceedings of the 15th International Conference on Coffee Science (ASIC '93), pp. 73-81, Montpellier, France, 1993.

[88] H. Etienne and M. Berthouly, "Temporary immersion systems in plant micropropagation," Plant Cell, Tissue and Organ Culture, vol. 69, no. 3, pp. 215-231, 2002.

[89] J. Albarrán, B. Bertrand, M. Lartaud, and H. Etienne, "Cycle characteristics in a temporary immersion bioreactor affect regeneration, morphology, water and mineral status of coffee (Coffea arabica) somatic embryos," Plant Cell, Tissue and Organ Culture, vol. 81, no. 1, pp. 27-36, 2005.

[90] M. F. Carneiro and T. M. O. Ribeiro, "In vitro meristem culture and plant regeneration in some genotypes of Coffea arabica," Broteria Genetica, vol. 85, pp. 127-138, 1989.

[91] M. Berthouly, D. Alvarad, C. Carrasco, and C. Teisson, "In vitro micropropagation of coffee sp. By temporary immersion," in Abstracts Eighth International Congress of Plant Tissue and Cell Culture, p. 162, Florence, Italy, 1994.

[92] C. Teisson, D. Alvard, M. Berthouly, F. Cote, J. V. Escalant, and H. Etienne, "Culture in vitro par immersion temporaire un nouveau récipient," Plantations, Recherche, Développement, vol. 2, no. 5, pp. 29-31, 1995.

[93] J. P. Ducos, R. Alenton, J. F. Reano, C. Kanchanomai, A. Deshayes, and V. Pétiard, "Agronomic performance of Coffea canephora P. trees derived from large-scale somatic embryo production in liquid medium," Euphytica, vol. 131, no. 2, pp. 215-223, 2003.

[94] M. R. Sondahl, W. R. Romig, and A. Bragin, "Induction and selection of somaclonal variation in coffee," US patent 5436395, 1995.

[95] V. M. Loyola-Vargas, C. Fuentes, M. Monforte-Gonzalez, M. Mendez-Zeel, R. Rojas, and J. Mijangos-Cortes, "Coffee tissue culture as a new modelfor the study of somaclonal variation," in Proceedings of the 18th International Conference on Coffee Science (ASIC'99), pp. 302-307, Paris, France, 1999.

[96] L. F. Sanchez-Teyer, F. R. Quiroz-Figueroa, V. M. LoyolaVargas, and D. Infante-Herrera, "Culture-induced variation in plants of Coffea arabica cv. Caturra rojo, regenerated by direct and indirect somatic embryogenesis," Molecular Biotechnology, vol. 23, no. 2, pp. 107-115, 2003.

[97] V. Rani, K. P. Singh, B. Shiran et al., "Evidence for new nuclear and mitochondrial genome organizations among high-frequency somatic embryogenesis-derived plants of allotetraploid Coffea arabica L. (Rubiaceae)," Plant Cell Reports, vol. 19, no. 10, pp. 1013-1020, 2000. 
[98] D. Ganesh and H. L. Sreenath, "Embryo culture in coffee: technique and applications," Indian Coffee, vol. 4, pp. 7-9, 1999.

[99] G. de Moro, M. Modonut, E. Asquini, P. Tornincasa, A. Pallavicini, and G. Graziosi, "Development and analysis of an EST databank of Coffea arabica," in Proceedings of the 6th Solanaceae Genome Workshop, p. 127, New Delhi, India, 2009.

[100] K. V. Satyanarayana, V. Kumar, A. Chandrashekar, and G. A. Ravishankar, "Isolation of promoter for $N$-methyltransferase gene associated with caffeine biosynthesis in Coffea canephora," Journal of Biotechnology, vol. 119, no. 1, pp. 20-25, 2005.

[101] C. Hinniger, V. Caillet, F. Michoux et al., "Isolation and characterization of cDNA encoding three dehydrins expressed during Coffea canephora (Robusta) grain development," Annals of Botany, vol. 97, no. 5, pp. 755-765, 2006.

[102] A. J. Simkin, T. Qian, V. Caillet et al., "Oleosin gene family of Coffea canephora: quantitative expression analysis of five oleosin genes in developing and germinating coffee grain," Journal of Plant Physiology, vol. 163, no. 7, pp. 691-708, 2006.

[103] S. Noir, F. Anthony, B. Bertrand, M. C. Combes, and P. Lashermes, "Identification of a major gene (Mex-1) from Coffea canephora conferring resistance to Meloidogyne exigua in Coffea arabica," Plant Pathology, vol. 52, no. 1, pp. 97-103, 2003.

[104] N. S. Prakash, D. V. Marques, V. M. P. Varzea, M. C. Silva, M. C. Combes, and P. Lashermes, "Introgression molecular analysis of a leaf rust resistance gene from Coffea liberica into C. arabica L," Theoretical and Applied Genetics, vol. 109, no. 6, pp. 1311-1317, 2004.

[105] E. K. Gichuru, M. C. Combes, E. W. Mutitu et al., "Characterization and genetic mapping of a gene conferring resistance to coffee berry disease (Colletotrichum kahawae) in Arabica coffee (Coffea arabica)," in Proceedings of the 21st International Conference on Coffee Science (ASIC '06), pp. 786-793, Montpellier, France, 2006.

[106] S. Ogita, H. Uefuji, Y. Yamaguchi, N. Koizumi, and H. Sano, "RNA interference: producing decaffeinated coffee plants," Nature, vol. 423, no. 6942, p. 823, 2003.

[107] V. Sridevi, P. Giridhar, P. S. Simmi, and G. A. Ravishankar, "Direct shoot organogenesis on hypocotyl explants with collar region from in vitro seedlings of Coffea canephora Pierre ex. Frohner cv. C $\times$ R and Agrobacterium tumefaciensmediated transformation," Plant Cell, Tissue and Organ Culture, vol. 101, no. 3, pp. 339-347, 2010.

[108] T. Leroy and M. Dufour, "Coffea spp. Genetic transformation," in Transgenic Crops of the World: Essential Protocols, I. S. Curtis, Ed., pp. 159-170, Kluwer Academic Publishers, Dordrecht, The Netherlands, 2004.

[109] T. Leroy, M. Royer, M. Paillard et al., "Introduction de genes $\mathrm{d}$ interet agronomique dans I'espece Coffea canephora Pierre par transformation avec Agrobacterium sp," in Proceedings of the 17th International Conference on Coffee Science (ASIC'97), pp. 439-446, Nairobi, Kenya, 1997.

[110] J. van Boxtel, A. Eskes, and M. Berthouly, "Glufosinate as an efficient inhibitor of callus proliferation in coffee tissue," In Vitro Cellular \& Developmental Biology-Plant, vol. 33, no. 1, pp. 6-12, 1997.

[111] N. P. Samson, C. Campa, M. Noirot, and A. de Kochko, "Potential use of D-xylose for coffee transformation," in Proceedings of the 20th International Conference on Coffee Science (ASIC '04), pp. 707-713, Bangalore, India, 2004.
[112] M. K. Mishra, S. Devi, A. McCormac et al., "Green fluorescent protein as a visual selection marker for coffee transformation," Biologia, vol. 65, no. 4, pp. 639-646, 2010.

[113] B. Perthuis, T. Leroy, M. Dufour et al., "Variability in the insecticidal protein concentration within transformed Coffea canephora observed in a field experiment," in Proceedings of the 21st International Cconference on Coffee Science (ASIC '06), pp. 1390-1393, Montpellier, France, September 2006.

[114] C. Montagnon, "Genetically modified coffees- the experience of CIRAD," in ICO seminar on Genetically Modified Coffee Workshop, May 2005, http://dev.ico.org/event_pdfs/gm/presentations/Christophe\%20Montagnon.pdf.

[115] I. Méndez-López, R. Basurto-Ríos, and J. E. Ibarra, “Bacillus thuringiensis serovar israelensis is highly toxic to the coffee berry borer, Hypothenemus hampei Ferr. (Coleoptera: Scolytidae)," FEMS Microbiology Letters, vol. 226, no. 1, pp. 73-77, 2003.

[116] M. F. Grossi de Sa, R. A. Pereira, E. V. S. A. Barros et al., "Uso de inibidores de alfa-amilases no controle da broca-do-cafe," in Anais do workshop Internacional de Manejo da Broca-docafe, Paraná, Brazil, 2004.

[117] V. P. Campos, P. Sivapalan, and N. C. Gnanapragasam, "Nematode parasites of coffee, cocoa and tea," in Plant Parasitic Nematodes in Subtropical and Tropical Agriculture, M. Luc, R. A. Sikora, and J. Bridge, Eds., pp. 113-126, CAB International, Wallingford, UK, 1990.

[118] B. Bertrand, F. Anthony, and P. Lashermes, "Breeding for resistance to Meloidogyne exigua in Coffea arabica by introgression of resistance genes of Coffea canephora," Plant Pathology, vol. 50, no. 5, pp. 637-643, 2001.

[119] M. M. Chaves, J. P. Maroco, and J. S. Pereira, "Understanding plant responses to drought-from genes to the whole plant," Functional Plant Biology, vol. 30, no. 3, pp. 239-264, 2003.

[120] M. M. Chaves and M. M. Oliveira, "Mechanisms underlying plant resilience to water deficits: prospects for water-saving agriculture," Journal of Experimental Botany, vol. 55, no. 407, pp. 2365-2384, 2004.

[121] I. Coraggio and R. Tuberosa, "Molecular basis of plant adaptation to abiotic stress and approaches to enhance tolerance to hostile environment," in Hand Book of Plant Biotechnology, P. Christou and H. Klee, Eds., pp. 413-466, John Wiley \& Sons, West Sussex, UK, 2004.

[122] H. A. M. van der Vossen, "Agronomy I: coffee breeding practices," in Coffee: Recent Developments, R. J. Clarke and O. G. Vitzthum, Eds., pp. 184-201, Blackwell Science, London, UK, 2001.

[123] M. S. Sreenivasan, "Breeding for leaf rust resistance in India," in Coffee Rust: Epidemiology, Resistance and Management, A. C. Kushalappa and A. B. Eskes, Eds., pp. 316-323, CRC Press, Boca Raton, Fla, USA, 1989.

[124] B. J. Staskawicz, F. M. Ausubel, B. J. Baker, J. G. Ellis, and J. D. G. Jones, "Molecular genetics of plant disease resistance," Science, vol. 268, no. 5211, pp. 661-667, 1995.

[125] B. J. Feys and J. E. Parker, "Interplay of signaling pathways in plant disease resistance," Trends in Genetics, vol. 16, no. 10, pp. 449-455, 2000.

[126] F. L. W. Takken and M. H. A. J. Joosten, "Plant resistance genes: their structure, function and evolution," European Journal of Plant Pathology, vol. 106, no. 8, pp. 699-713, 2000.

[127] X. Dong, "SA, JA, ethylene, and disease resistance in plants," Current Opinion in Plant Biology, vol. 1, no. 4, pp. 316-323, 1998. 
[128] M. P. Does and B. J. C. Cornelissen, "Emerging strategies to control fungal diseases using transgenic plants," in in proceedings of International Crop Science Congress, V. L. Chopra, R. B. Singh, and A. Verma, Eds., pp. 233-244, Oxford and IBH, New Delhi, India, 1998.

[129] D. Fernandez, P. Santos, C. Agostini et al., "Coffee (Coffea arabica L.) genes early expressed during infection by the rust fungus (Hemileia vastatrix)," Molecular Plant Pathology, vol. 5, no. 6, pp. 527-536, 2004.

[130] B. de Nardi, R. Dreos, L. Del Terra et al., "Differential responses of Coffea arabica L. leaves and roots to chemically induced systemic acquired resistance," Genome, vol. 49, no. 12, pp. 1594-1605, 2006.

[131] K. David, "Fun without the buzz: decaffeination process and issues," 2002, http://www.virtualcoffee.com/sept_2002/decafe.html.

[132] M. N. Clifford, "Chemical and physical aspects of green coffee and coffee products," in Coffee: Botany Biochemistry and Production of Beans and Beverages, M. N. Clifford and K. C. Williamson, Eds., pp. 304-374, AVI, Westport, Conn, USA, 1985.

[133] C. A. B. de Maria, L. C. Trugo, F. R. Aquino Neto, R. F. A. Moreira, and C. S. Alviano, "Composition of green coffee water-soluble fractions and identification of volatiles formed during roasting," Food Chemistry, vol. 55, no. 3, pp. 203-207, 1996.

[134] M. N. Clifford, "Chlorogenic acids and other cinnamatesnature, occurrence and dietary burden," Journal of the Science of Food and Agriculture, vol. 79, no. 3, pp. 362-372, 1999.

[135] C. Campa, M. Noirot, M. Bourgeois et al., "Genetic mapping of a caffeoyl-coenzyme A 3-0-methyltransferase gene in coffee trees. Impact on chlorogenic acid content," Theoretical and Applied Genetics, vol. 107, no. 4, pp. 751-756, 2003.

[136] K. Hahlbrock and D. Scheel, "Physiology and molecular biology of phenyl-propanoid metabolism," Annual Review of Plant Physiology and Plant Molecular Biololgy, vol. 40, pp. 347-369, 1989.

[137] V. Mahesh, J. J. Rakotomalala, L. L. Gal et al., "Isolation and genetic mapping of a Coffea canephora phenylalanine ammonia-lyase gene (CcPAL1) and its involvement in the accumulation of caffeoyl quinic acids," Plant Cell Reports, vol. 25, no. 9, pp. 986-992, 2006.

[138] G. Parvatam, V. Mahesh, G. A. Ravishankar, C. Campa, and A. de Kochko, "Functional validation of Coffea PAL genes using genetic engineering," in Proceedings of the 21st International Conference on Coffee Science (ASIC '06), pp. 702-705, Montpellier, France, September 2006.

[139] L. F. Protasio Pereira, R. M. Galvão, A. K. Kobayashi, S. M. B. Cação, and L. G. Esteves Vieira, "Ethylene production and ACC oxidase gene expression during fruit ripening of Coffea arabica L," Brazilian Journal of Plant Physiology, vol. 17, no. 3, pp. 283-289, 2005.

[140] K. R. Neupane, S. Moisyadi, and J. Stiles, "Cloning and characterization of fruit expressed ACC synthase and ACC oxidase from coffee," in In Proceedings of the 18th International Conference on Coffee Science (ASIC '99), pp. 322-326, Helsinki, Finland, 1999.

[141] A. F. Ribas, L. F. P. Pereira, and L. G. E. Vieira, "Genetic transformation of coffee," Brazilian Journal of Plant Physiology, vol. 18, no. 1, pp. 83-94, 2006. 

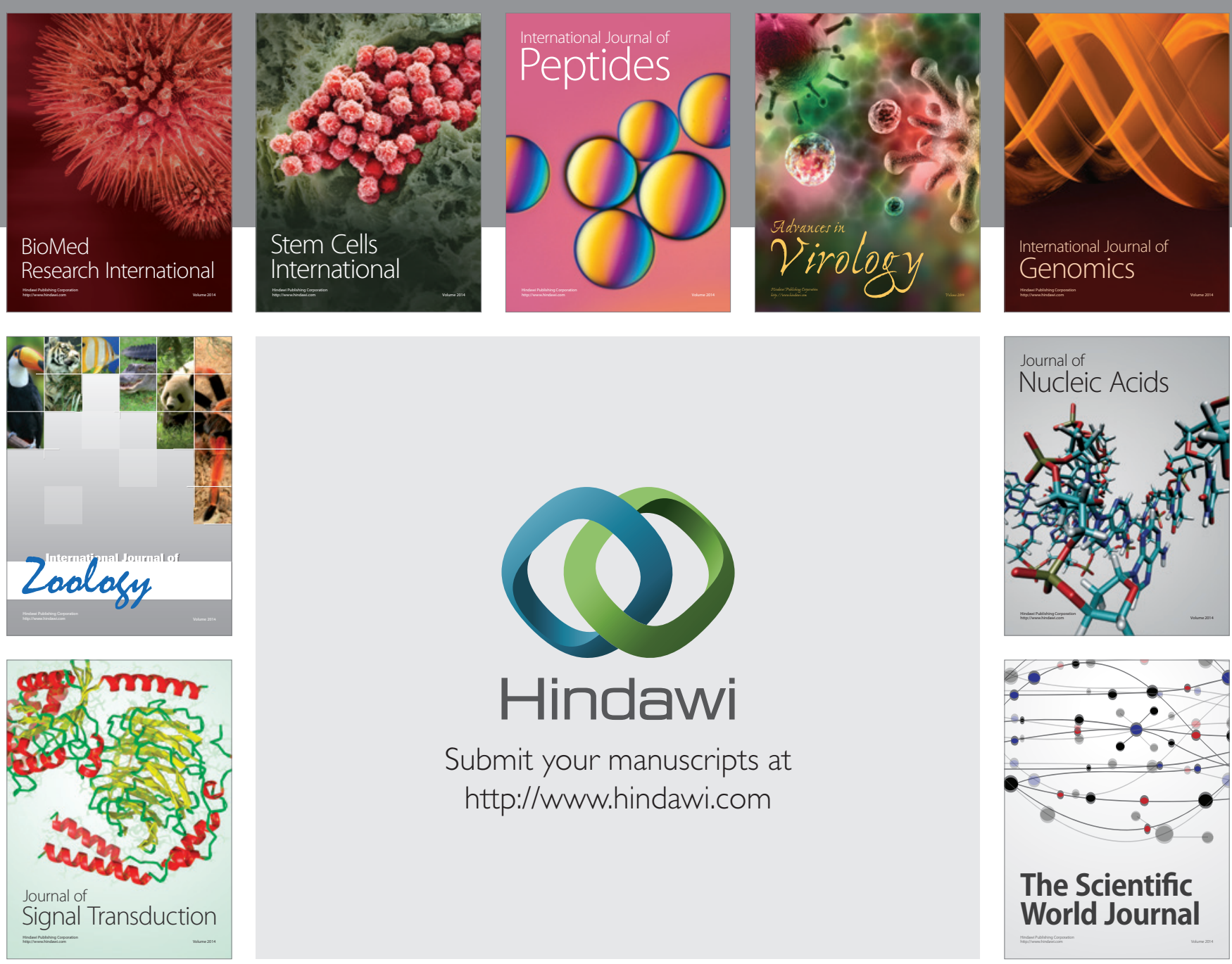

Submit your manuscripts at

http://www.hindawi.com
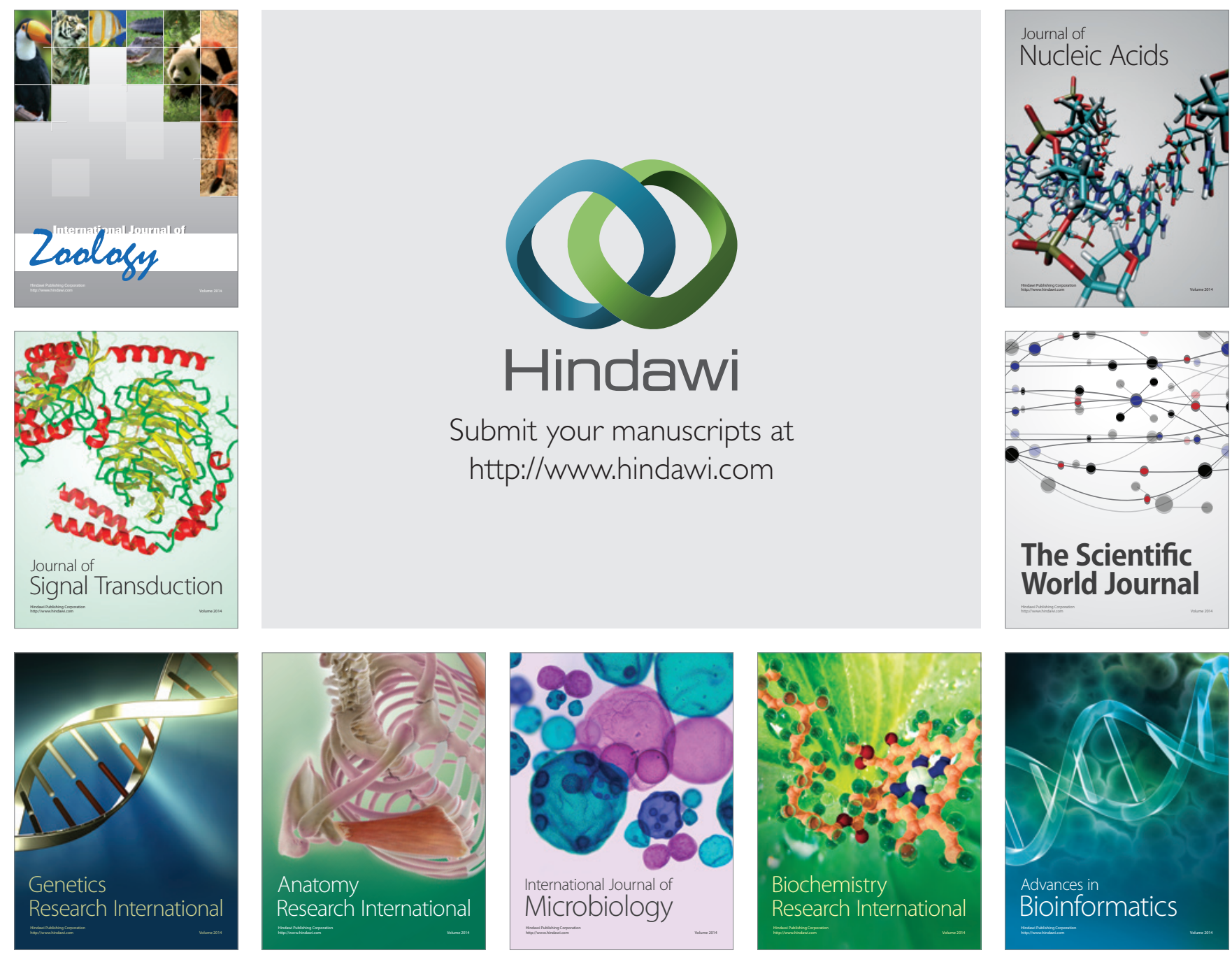

The Scientific World Journal
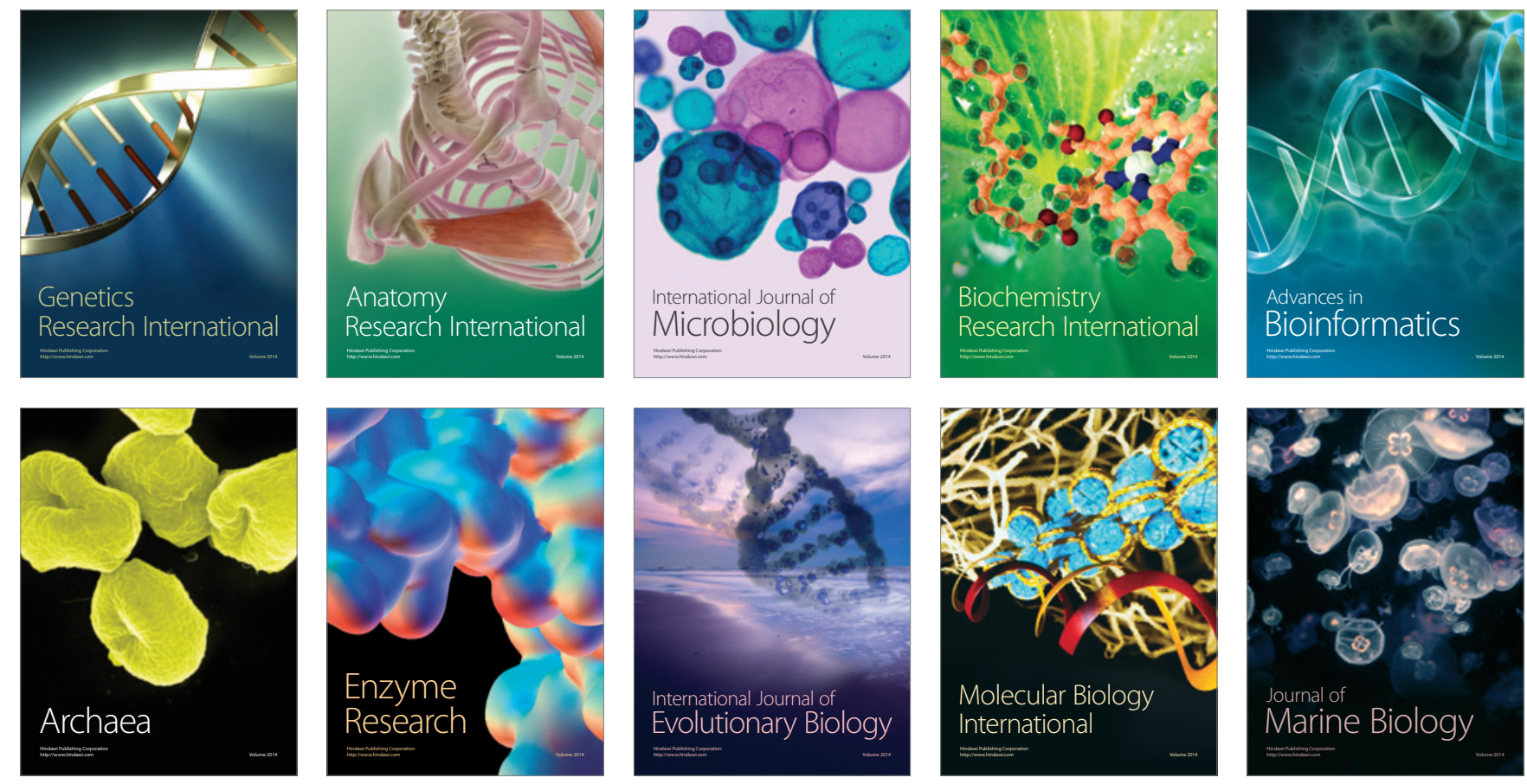